
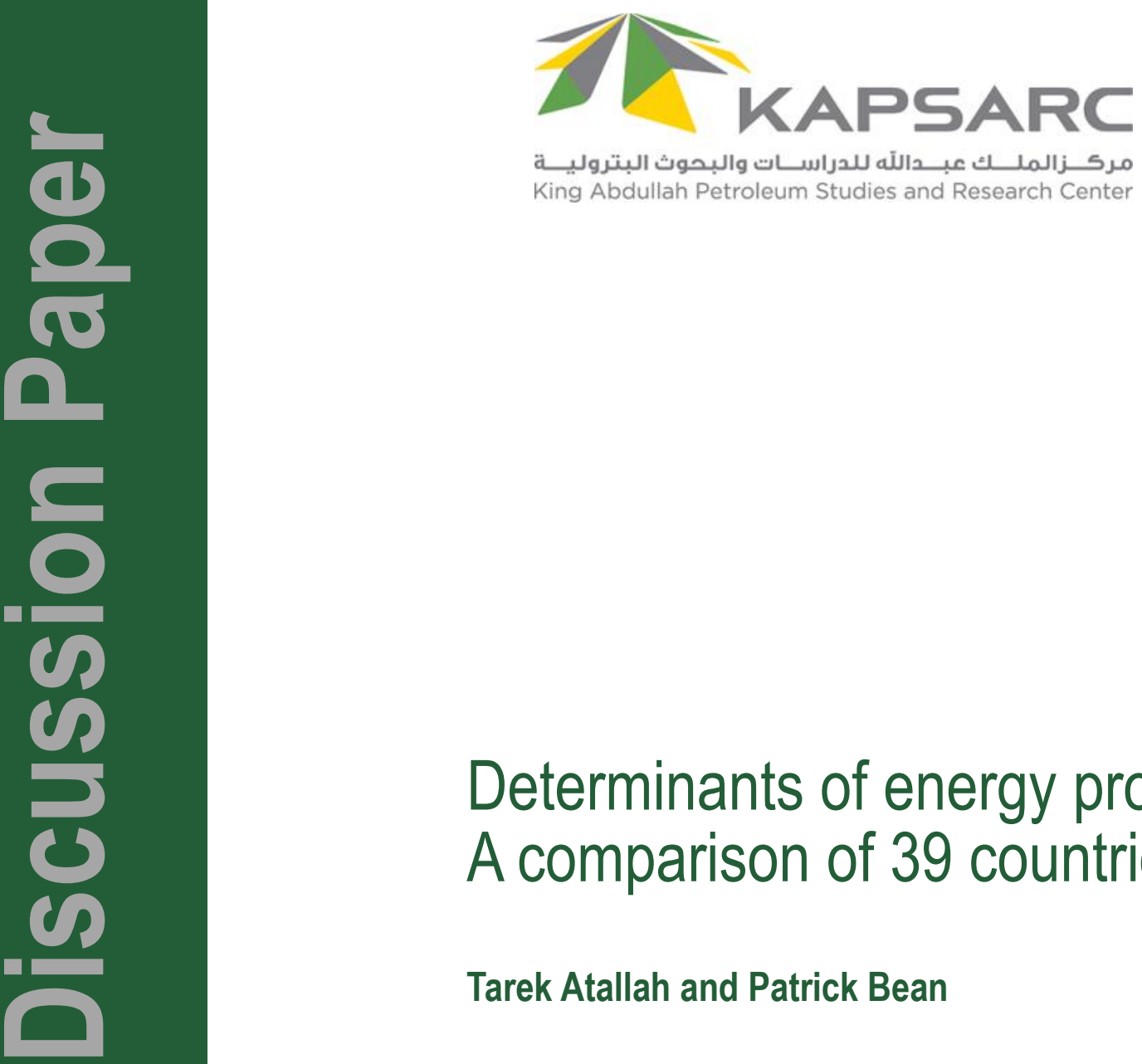

\title{
Determinants of energy productivity: A comparison of 39 countries
}

\author{
Tarek Atallah and Patrick Bean
}




\section{About KAPSARC}

The King Abdullah Petroleum Studies and Research Center (KAPSARC) is an independent, non-profit research institution dedicated to researching energy economics, policy, technology, and the environment across all types of energy. KAPSARC's mandate is to advance the understanding of energy challenges and opportunities facing the world today and tomorrow, through unbiased, independent, and high-caliber research for the benefit of society. KAPSARC is located in Riyadh, Saudi Arabia.

\section{Legal notice}

(C) Copyright 2015 King Abdullah Petroleum Studies and Research Center (KAPSARC). No portion of this document may be reproduced or utilized without the proper attribution to KAPSARC. 


\section{Summary}

Quantifying the determinants of a country's energy productivity trends answers the fundamental question of whether its economy is becoming more energy productive because of technological and efficiency gains, or whether it is due to structural economic shifts.

This paper uses three types of analysis to investigate the drivers of energy productivity changes occurring in 39 countries during the 1995-2009 period. Several key findings about global energy productivity trends emerged:

- Sectoral energy productivity improvements from efficiency gains and changes in product mix were the primary drivers behind country level energy productivity improvements.

- Structural economic shifts away from industry and towards more service-oriented sectors played a lesser role in aggregate energy productivity improvements.

- Nations with similar demographic and economic characteristics showed similar levels of energy productivity and rates of improvement.

- Former communist countries and nations undergoing economic liberalization exhibited the highest rates of improvement - although they remain less energy productive than developed nations.

- Long-standing hypotheses that higher levels of income per capita and higher energy prices are associated to greater energy productivity are reinforced by the analysis.

- Higher levels of investment are also associated with aggregate energy productivity improvements, although the response from the investments may take a few years to materialize.

\section{Introduction}

Energy productivity-defined as the ratio of economic output per unit of energy use - is a metric that can inform nations about their relative performance of interrelated (and sometimes competing) economic, energy, and environmental issues. For a number of years, productivity's reciprocal, intensity, has been recognized as a potentially valuable metric of performance and has informed energy and climate policies. Focus on energy productivity has grown in recent years as organizations and countries began developing targets. The United States' adopted goal of doubling energy productivity by 2030 (DOE, 2014), and Germany's goal of doubling energy productivity by 2020 relative to 1990 (Federal Ministry of Economic Affairs and Technology, 2006), are two such examples. Understanding the determinants of energy productivity is crucial if the metric is to expand its role in policy globally.

Energy productivity changes at an aggregate, economy-wide level occur through two basic effects: the sectoral energy productivity effect, and the structural effect.

Energy productivity changes at an aggregate, economy-wide level occur through two basic effects. The first is a change in sectoral energy productivity, which can arise from technological improvements, behavioral changes, changes in product mix not evident because of sectoral aggregation, and other factors. We refer to this as the sectoral energy productivity effect and it is also referred to as the energy efficiency effect. The second fundamental effect is a shift in the mix of economic activity. For example, if an economy's structure moves towards energy productive sectors like financial services, the aggregate energy productivity improves, even if the 
energy productivity of each sector remains the same. We refer to this determinant as the structural effect, also referred to as the activity effect.

Our paper investigates the effects driving economywide energy productivity changes in 39 countries between 1995 and 2009, using a decomposition analysis.

Demographic and economic conditions may play a role in a country's energy productivity performance and in different ways through sectoral energy productivity and structural effects. The potential associations between those effects and demographic and economic indicators - such as energy prices and income per capita - are analyzed using cluster and econometric analyses. Supplemental information about analysis methodologies and data are available in the Appendix.

\section{Exploring the determinants}

Our analysis is based on a time-series of sectoral gross output and energy consumption data for 39 countries from the World Input Output Database (WIOD) (Timmer, 2012) (see Table below). Data for each country is disaggregated to 34 commercial and industrial sectors (see Table 9). The residential sector is excluded at this stage of the research. Key developed and emerging economies are included in the dataset, and in total the 39 countries account for nearly $85 \%$ of global GDP and $80 \%$ of energy consumption.

\section{Performance of countries and sectors}

Energy productivity varies substantially between countries and sectors. "Financial Intermediation" is the most energy productive sector with a weighted

\section{Countries included in the analysis}

\begin{tabular}{ccc}
\hline Australia & Germany & Netherlands \\
Austria & Greece & Poland \\
Belgium & Hungary & Portugal \\
Brazil & India & Romania \\
Bulgaria & Indonesia & Russia \\
Canada & Ireland & Slovak Republic \\
China & Italy & Slovenia \\
Cyprus & Japan & South Korea \\
Czech Republic & Latvia & Spain \\
Denmark & Lithuania & Sweden \\
Estonia & Luxembourg & Turkey \\
Finland & Malta & United Kingdom \\
France & Mexico & United States \\
\hline
\end{tabular}


average for all countries of over \$2 million (1995\$)/ TJ. "Electricity, Gas and Water Supply" was the least energy productive sector at about $\$ 10,000 / \mathrm{TJ}$, while also being the largest energy consuming sector-accounting for over $45 \%$ of the energy consumption in the dataset. A wide performance gap between countries also exists. Ireland is the most energy productive country in the dataset at $\$ 511,000 /$ TJ, while Russia is the least energy productive at roughly $\$ 33,000 / \mathrm{TJ}$.

Energy productive sectors had high rates of improvement, as did several less energy productive sectors. For example, the "Coke and Refined
Products" sector improved at a $6 \%$ annualized (geometric mean) rate between 1995-2009. Globally, three sectors became less energy productive during the study period. These include the "Pulp, Paper, and Publishing," "Other NonMetallic Mineral," and "Other Transport Activities" sectors. The declines were due in part to declining value added margins in countries with a large market share, including Japan and the United States. Figure 1 shows the relationship between annualized improvement and weighted average energy productivity for each sector. (See Tables 6-7 for additional country and sectoral statistics).

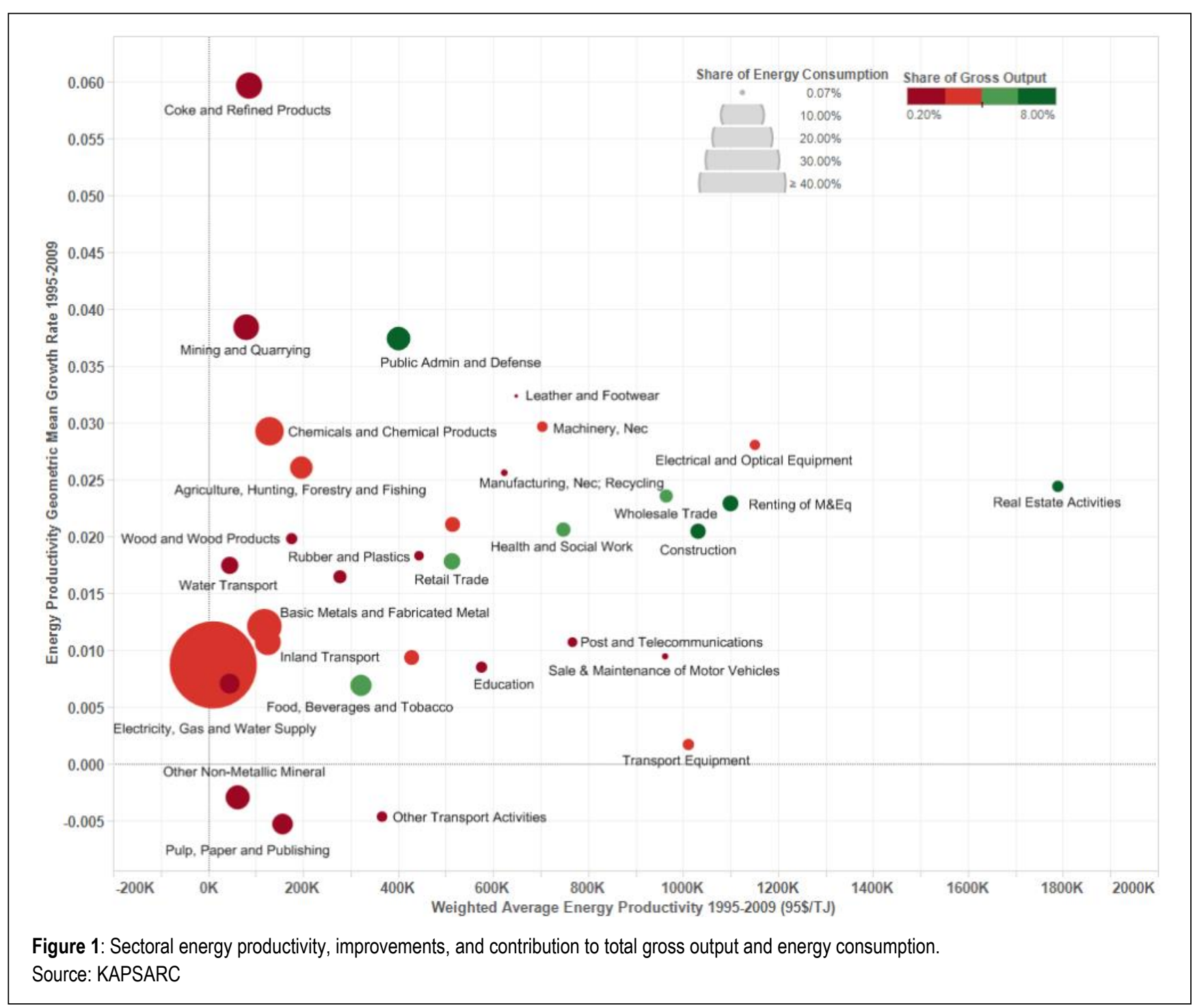




\section{Changes in energy productivity: A decomposition}

Using a Fisher Ideal Index Decomposition approach to decompose energy productivity changes, our analysis shows the majority of country-level increases were a result of sectoral energy productivity improvements rather than structural economic shifts (Figure 2). Regarding the pace of improvement, there is a potential correlation between market liberalization and energy productivity gains. Ten of the top eleven improvements came from Eastern European countries that transitioned during the study period following the fall of Soviet Union and communism. The countries improved their energy productivity through a mix of improvements in both the sectoral energy productivity and structural effects-although Latvia is an exception as its structure shifted to a more energy intensive composition. Gross output in service sectors grew at a faster rate than energy intensive industries and thus increased their share of economic output as the nations developed more liberalized markets.

There is a potential correlation between market liberalization and energy productivity gains.

The tenth largest improvement was the $143 \%$ gain in China-which introduced market reforms. China's improvement was due entirely to gains in sectoral energy productivity, while industrialization efforts were a drag in performance. Energy intensive sectors including "Electricity, Gas and Water Supply" increased their share of economic output at the expense of energy productive sectors like "Financial Intermediation" and "Wholesale Trade". The gains in sectoral energy productivity may be associated with technological transfer and potential leap-frogging that accompanied the rapid expansion of the Chinese economy. Our findings are similar to those of Song and Zheng (2012) which found 90\% of China's energy intensity improvement between 1995 and 2009 was due to the energy efficiency effect (analogous to our sectoral energy productivity effect).

Other emerging economies including Indonesia, Brazil and Mexico, experienced a similar improvement pattern to China, albeit to a lesser extent. These countries showed improvements in sectoral energy productivity, up to $56 \%$ in the case of Mexico, but the gains were counterbalanced by industrialization and the resulting structural economic shifts towards more energy intensive sectors. In Indonesia's case, structural shifts completely offset sectoral energy productivity improvements, and led to a $6 \%$ decline in aggregate energy productivity.

Smaller percent gains in aggregate energy productivity are seen in developed economies including Australia, Canada, United Kingdom, USA, and Western Europe. The improvements were driven by both effects, but predominately by the sectoral energy productivity effect. Our decomposition for the USA matches the findings from Metcalf (2008) that sectoral energy productivity (or intensity) improvements account for $75 \%$ of the aggregate productivity improvement.

Many of these developed countries, especially those in Western Europe, exhibited similar patterns in the sectoral energy productivity and structural effects. This reinforces the potential of energy productivity convergence spurred by flows of technology and intellectual capital within the European Union. The general trend is of energy efficiency increases for most of these countries beginning after 2001. An increase in energy prices that led to more productive consumption may have caused this - a notion we 


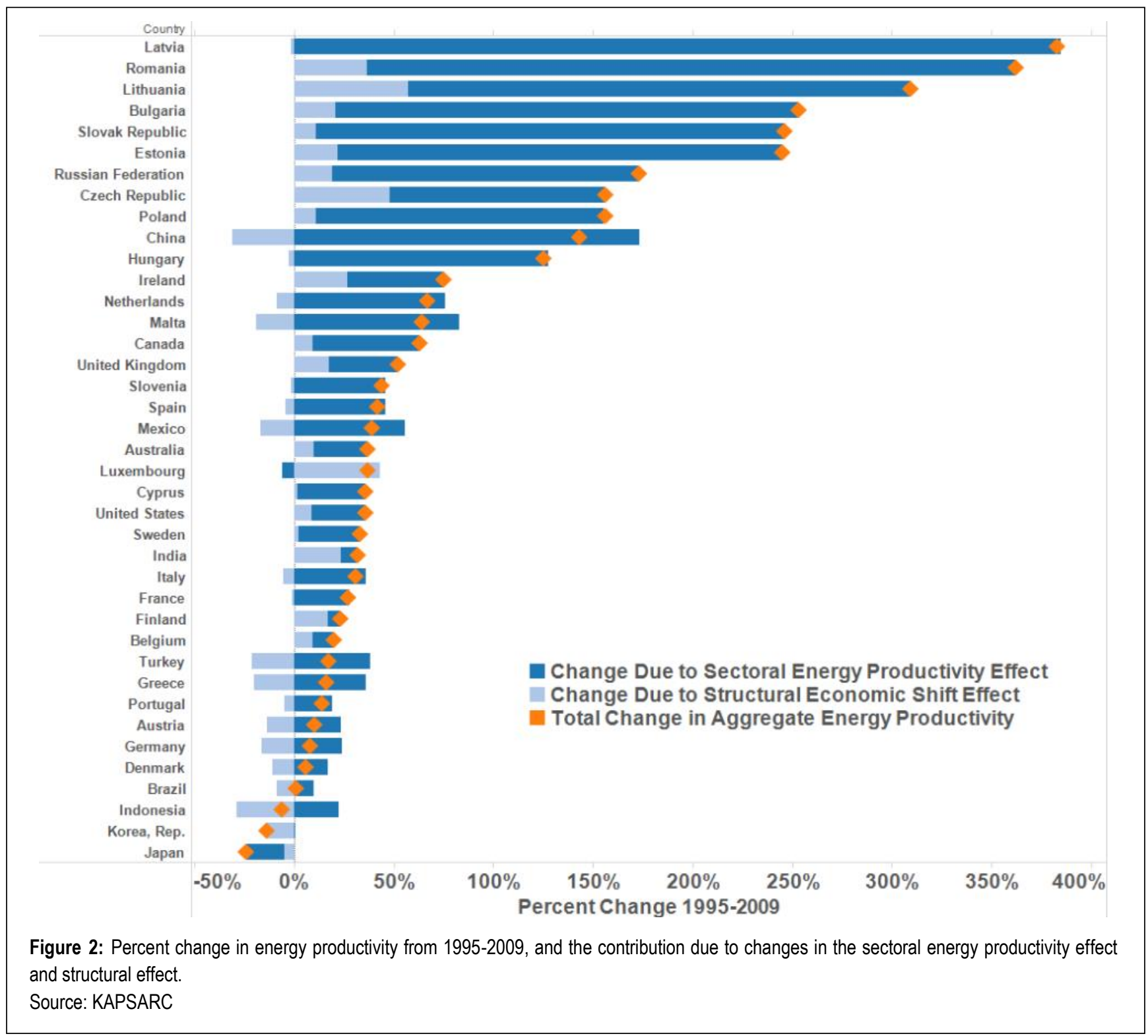

investigate in the subsequent econometric analysis. However, the effect of distortions following migration to the Euro currency and our use of gross output denominated in US dollars rather than Purchasing Power Parity (PPP) may also contribute to this result.

Japan, South Korea and Indonesia are the only countries in the dataset that experienced a reduction in their aggregate energy productivity. Indonesia was weighed down by a shift towards energy intensive sectors including "Mining and Quarrying" and
"Electricity, Gas, and Water Supply", while the share of output for "Financial Intermediation" fell, and the devastating effects of the 2004 tsunami reduced the share of output from the "Hotels \& Restaurants" sector. Although South Korea's relatively energy productive vehicle manufacturing sector increased its share of gross output, it was offset by growth in energy intensive sectors like "Coke and Refined Products" and "Electricity, Gas, and Water Supply." Japan's overall decline, on the other hand, was due to energy productivity declines in 28 of the 34 sectors. Most notably between 1995 and 2009, the energy 
productivity of its "Other Transport Activities", "Mining and Quarrying", and "Wood and Wood Products" sectors declined 55\%, 50\%, and $42 \%$, respectively.

Sectoral energy productivity improvements occurred in a more accelerated and volatile fashion than structural changes.

Another potential cause for the decline of the Japanese productivity could be the utilization of Market Exchange Rates (MER) instead of Purchasing Power Parity (PPP) for monetary international comparisons. The period 1995-2009 was referred to as Japan's lost decade and was characterized by a decline in the nominal value of the Yen exchange rate, which translated into stagnant GDP values. Sectorial PPP deflators are not readily available, leaving limited options for replacing MER based figures.

Across the 39 country sample, the analysis shows sectoral energy productivity improvements occurred in a more accelerated and volatile fashion than structural changes (See Figure 3 for select countries, and Appendix Table 8 for additional results). This is intuitive because transitioning an economy towards more energy productive sectors can take years or even decades. The sometimes rapid change in sectoral energy productivity can arise from changes in the product mix within sectors, labor or behavioral changes, or technological energy efficiency gains among other factors.

\section{Clustering countries by their characteristics and energy productivity performance}

Although changes in energy productivity can be decomposed into the two core effects described above, economic and demographic conditions may also play a role in a country's performance. For example, rising energy prices may be associated with energy productivity improvements. Yet the extent to which rising energy prices are associated with sectoral energy productivity gains or structural economic shifts is unclear.

We also incorporate a cluster analysis to help identify countries with similar demographic and economic characteristics and to assess whether the country clusters share similar energy productivity trends. The 39 countries were delineated into three groups using a K-means clustering approach.

The economic and demographic indicators evaluated include energy prices, income per capita, degree days and others that can influence economic output and energy consumption levels, and thus energy productivity. (See Table 1 for the variables and further discussion in Appendix II).

The Fisher decomposition indices were excluded from the cluster analysis so that an analysis of variance (ANOVA) can test whether the energy productivity indices associated with the countries differ between clusters. The ANOVAs show statistically significant differences exist among the three clusters in terms of energy productivity, Fisher Aggregate Energy Productivity Index, Fisher Sectoral Energy Productivity Index, and Fisher Structural Index. Mean values for the demographic and economic variables, and the exogenous energy productivity indices are provided by cluster in Table 2 .

The analysis yields clear geographic or socioeconomic delineations that are commonly used to classify the countries (Table 3). Cluster 1 includes emerging economies including the BRICs (Brazil, Russia, India, and China), Indonesia, Mexico and Turkey. Many OECD nations - including Australia, Japan, USA, and Western European nations - make up Cluster 2, while former communist states in Eastern Europe are in Cluster 3. 


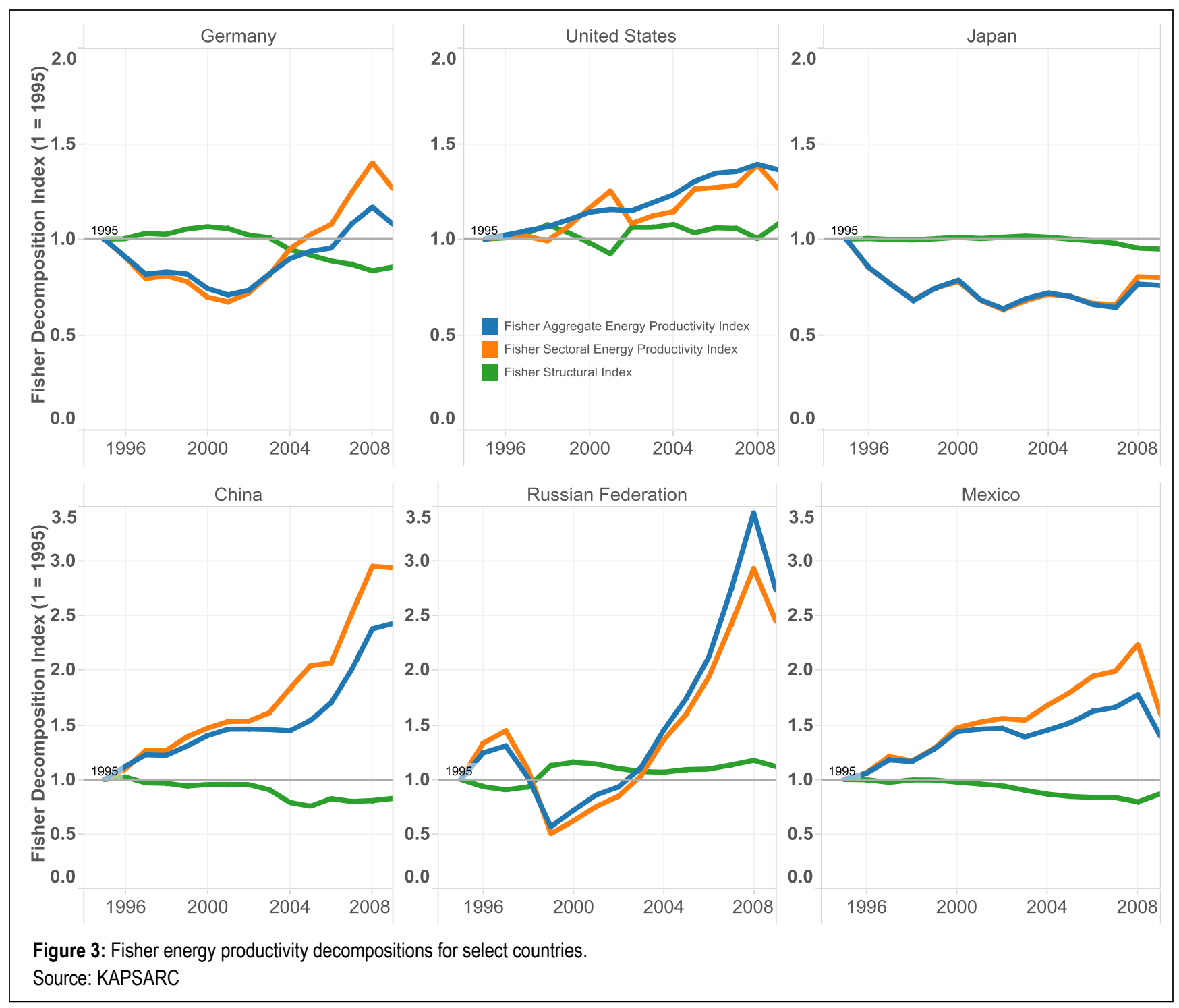

\begin{tabular}{|l|c|c|}
\hline & Cluster Analysis & Econometric Analysis \\
\hline Weighted average energy prices & $\checkmark$ & $\checkmark$ \\
\hline Total degree days & $\checkmark$ & $\checkmark$ \\
\hline Income per capita & $\checkmark$ & $\checkmark$ \\
\hline Industry value added as a percent of GDP & $\checkmark$ & \\
\hline Investment to capital ratio & $\checkmark$ & \\
\hline Perceived energy security index & $\checkmark$ & \\
\hline Population growth rate & $\checkmark$ & \\
\hline Urban population as a percent of total population & $\checkmark$ & \\
\hline Female labor participation rate & $\checkmark$ & \\
\hline Table 1: Explanatory variables included in the cluster and econometric analysis. & & \\
Source: KAPSARC & & \\
\hline
\end{tabular}


The validity of the clusters is confirmed by plotting two variables exogenous to the cluster analysis for each country: the annualized (geometric mean) energy productivity growth rate and weighted average energy productivity (Figure 4). The clustering of former communist countries of Eastern Europe is very clear. The countries are small, and exhibit high rates of improvement but low aggregate energy productivity levels. On the other hand, BRICs and other industrializing countries, including Mexico and Indonesia, exhibit lower energy productivity but slower rates of improvement also.
The analysis yields clear geographic and socioeconomic delineations that are commonly used to classify the countries.

Emerging economies in Cluster 1 are characterized by low aggregate energy productivity and slow rate of aggregate energy productivity improvement. All countries in the cluster, except India and Russia, experienced shifts towards more energy intensive sectors as seen in the Fisher Structural Index (and Figure 2). Moreover, industry's contribution to GDP is the highest on average in Cluster 1, suggesting a

\begin{tabular}{|c|c|c|c|c|c|c|c|c|c|c|c|c|c|}
\hline & \multicolumn{9}{|c|}{ Endogenous to Cluster Analysis } & \multicolumn{4}{|c|}{ Exogenous to Cluster Analysis } \\
\hline & $\begin{array}{l}\text { Urban } \\
\text { Population } \\
\text { (\% of total) }\end{array}$ & $\begin{array}{l}\text { Investment } \\
\text { to Capital } \\
\text { Ratio }\end{array}$ & $\begin{array}{l}\text { Female } \\
\text { Labor } \\
\text { Particpation } \\
\text { Rate }\end{array}$ & $\begin{array}{l}\text { Population } \\
\text { Growth }\end{array}$ & $\begin{array}{l}\text { GNI per } \\
\text { Capita } \\
\text { (1995 } \\
\text { US\$) }\end{array}$ & $\begin{array}{l}\text { Perceived } \\
\text { Energy } \\
\text { Security } \\
\text { Index of } \\
\text { Imports }\end{array}$ & $\begin{array}{l}\text { Industry } \\
\text { Value } \\
\text { Added } \\
\text { (\% of } \\
\text { Total) }\end{array}$ & $\begin{array}{l}\text { Total } \\
\text { Degree } \\
\text { Days }\end{array}$ & $\begin{array}{l}\text { Energy } \\
\text { Price } \\
\text { Index } \\
\text { (1995 } \\
\text { US\$/TJ) }\end{array}$ & $\begin{array}{l}\text { Energy } \\
\text { Productivity } \\
\text { (Thousands, } \\
\text { 1995 US\$/ } \\
\text { TJ) }\end{array}$ & $\begin{array}{l}\text { Fisher } \\
\text { Aggregate } \\
\text { Energy } \\
\text { Productivity } \\
\text { Index }\end{array}$ & $\begin{array}{l}\text { Fisher } \\
\text { Sectoral } \\
\text { Energy } \\
\text { Productivity } \\
\text { Index }\end{array}$ & $\begin{array}{l}\text { Fisher } \\
\text { Structural } \\
\text { Index }\end{array}$ \\
\hline Cluster 1 & $58 \%$ & 0.080 & $47 \%$ & $1.09 \%$ & $\$ 2,859$ & 0.07 & $35 \%$ & 5374 & $\$ 822$ & $\$ 125$ & 1.15 & 1.23 & 0.94 \\
\hline Cluster 2 & $77 \%$ & 0.070 & $51 \%$ & $0.69 \%$ & $\$ 24,88$ & 0.29 & $28 \%$ & 5535 & $\$ 938$ & $\$ 279$ & 1.04 & 1.02 & 1.02 \\
\hline Cluster 3 & $63 \%$ & 0.056 & $50 \%$ & $-0.29 \%$ & $\$ 5,914$ & 0.41 & $32 \%$ & 7271 & $\$ 835$ & $\$ 117$ & 1.88 & 1.67 & 1.11 \\
\hline Total & $70 \%$ & 0.068 & $50 \%$ & $0.51 \%$ & $\$ 16,06$ & 0.28 & $30 \%$ & 5951 & $\$ 891$ & $\$ 210$ & 1.28 & 1.23 & 1.03 \\
\hline
\end{tabular}

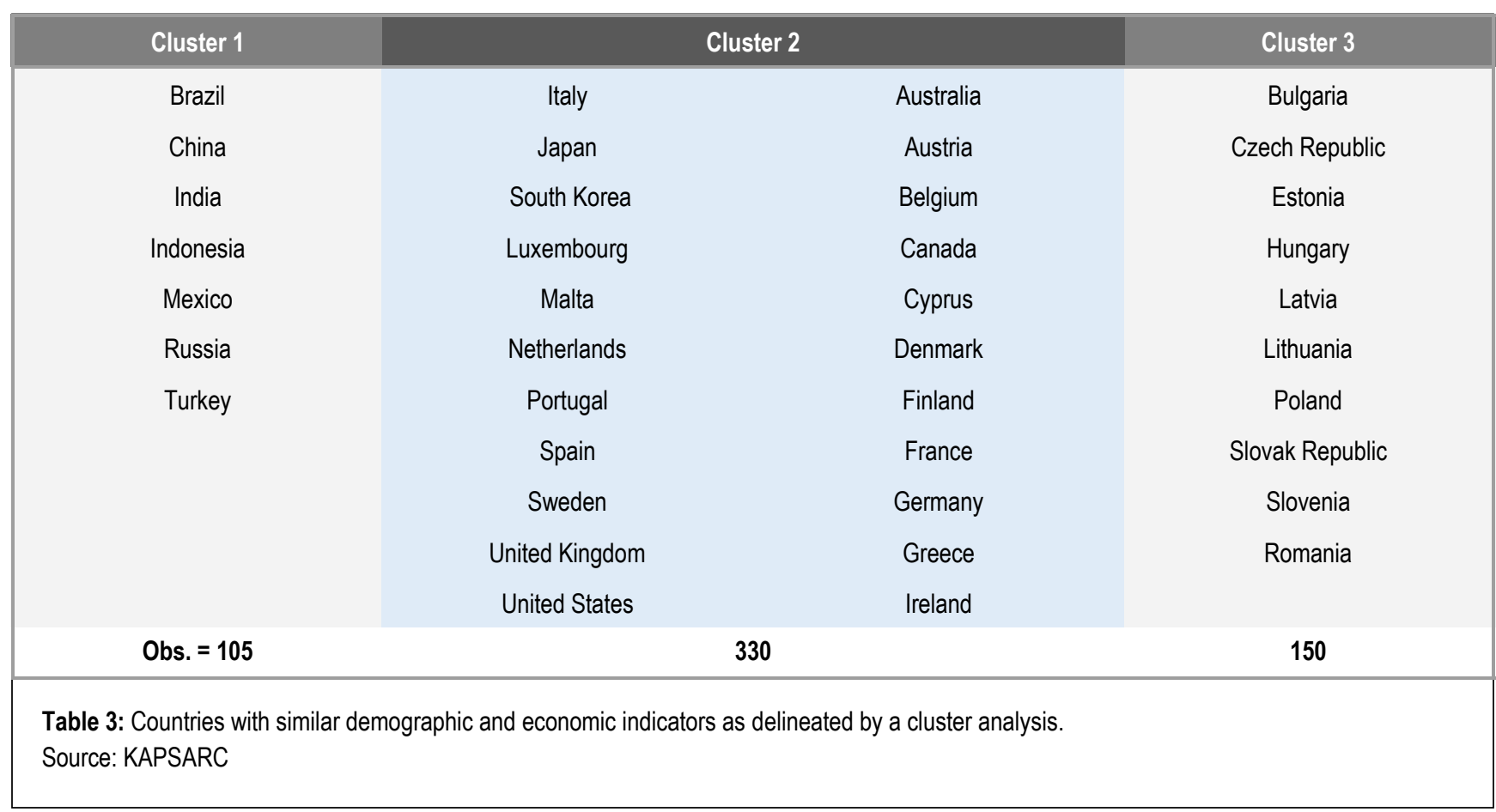




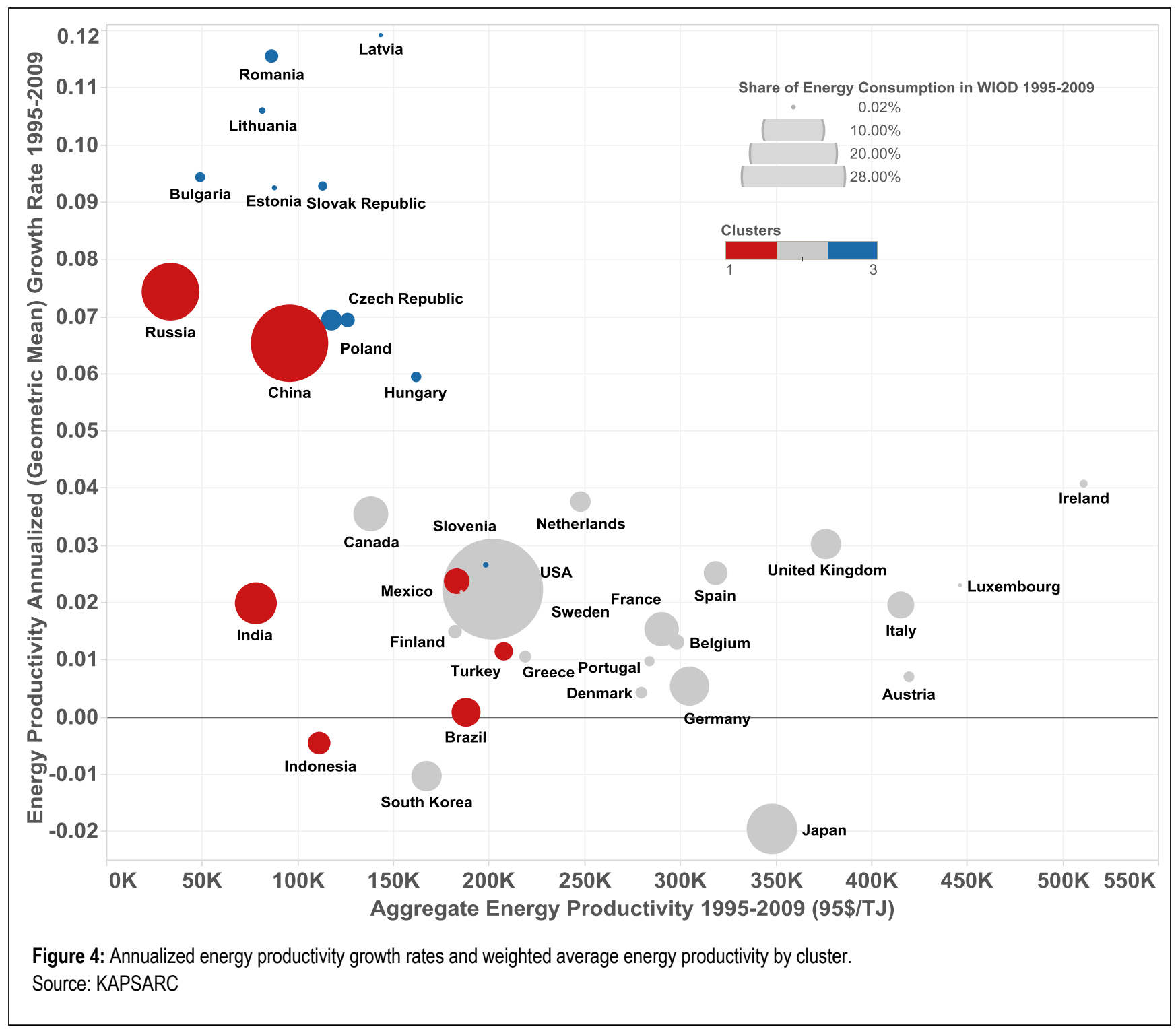

clear relationship between the two variables. The cluster has the lowest female labor participation rate and share of urban population, but the highest average population growth rate. Cluster 1 countries are the poorest in the analysis, but have the highest investment to capital ratio. This may have a positive influence on sectoral energy productivity as more efficient equipment is utilized. Alternatively, it may have a negative impact if investment is expanding for energy intensive industries. Cluster 1 has the lowest perceived energy security index of energy imports (PESI) and energy prices, perhaps a consequence of the resource rich nature of the countries, the presence of energy subsidies, or use of cheap domestic fuels such as coal.

On average, the most energy productive, wealthiest and service-oriented economies are in Cluster 2. Despite being the most energy productive, the rate of improvement is the lowest among the three clusters. This may suggest convergence in energy productivity, and that rates of energy productivity improvements diminish as gross national income (GNI) per capita increases. Also of note, Cluster 2 sees the highest average energy prices and urban populations. 
Eastern European nations in Cluster 3 have the lowest average energy productivity but the highest rates of improvement. Total degree days are higher than in Clusters 1 and 2, but there appears to be no clear associations between this geographic characteristic and energy productivity performance. Energy prices and GNI per capita are slightly higher on average than Cluster 1. Although the low relative energy prices and high rates of energy productivity improvement may be counterintuitive, the high PESI of imports score-suggesting they feel less secure or highly dependent on energy imports - may explain the higher rate of improvement. Population growth is negative throughout the cluster, and investment to capital ratio is the lowest on average in the dataset.

\section{Econometric analysis}

Moving away from country-specific dynamics, the 39 countries were pooled together in a panel econometric analysis to investigate associations between economic and demographic indicators and energy productivity from a global perspective.

The three Fisher indexes resulting from the decomposition analysis serve as the dependent variables in order to test whether some factors such as energy prices - are associated with changes in aggregate energy productivity, and if so, whether it is through sectoral productivity effects, structural effects, or both.

The number of demographic and economic indicators serving as independent variables was limited to five because, with only 15 years of observations, too many parameters can lead to spurious insights. The independent variables chosen were: weighted average energy prices, GNI per capita, total degree days (TDD), investment to capital ratio, and industry's value added as a percent of GDP (see Table 4 for variable summary statistics).
Since the 39 countries in the dataset are quite heterogeneous, we used a Pedroni (2001) panel cointegration approach with error correction model and period fixed effects. The estimation approach assumes that changes in the independent variables, such as like energy prices, elicit long and short term changes in the dependent variables - the energy productivity decomposition indexes. (Additional details about the econometrics methodology, and diagnostics for testing variable cointegration and stationarity are provided in the Appendix). Results are presented in Table 5

Beginning with the Fisher Aggregate Energy Productivity Index, we find a positive response on growth rates from higher growth rates of energy prices and income per capita at the $1 \%$ significance level. This energy price response is to be expected as increasing prices drive rationalization of consumption patterns and adoption of more efficient technologies and behaviors. Since economic output is the numerator in energy productivity, and economic output generally grows faster than energy use, the positive impact of GNI per capita is also to be expected. By contrast, the 1-year lag growth rate of GNI has a statistically significant negative impact on the following year's change in aggregate productivity. Despite this, the combined response is positive standing at around 0.85 for each unit of growth rate of GNI increase.

Higher growth rates in investment to capital ratio were found to have a positive association with energy productivity growth rates, albeit with a 2year lagged response. This finding supports the hypotheses that higher investment levels lead to more efficient technology, processes, and networks, and that the energy productivity benefits of those investments may have a delayed response.

Growth in industry's share of output and TDD are associated with negative responses in aggregate energy productivity at the $5 \%$ level, which is 


\begin{tabular}{|l|l|l|l|l|l|}
\hline Variable & Description & Mean & Standard & Minimum & Maximum \\
\hline Ln(Fisher_Aggregate_EP) & $\begin{array}{l}\text { Natural logarithm of the Fisher Aggregated Energy } \\
\text { Productivity Index }\end{array}$ & 0.14 & 0.41 & -0.93 & 1.83 \\
\hline Ln(Fisher_Sectoral_EP) & $\begin{array}{l}\text { Natural logarithm of the Fisher Sectoral Energy } \\
\text { Productivity Index }\end{array}$ & 0.12 & 0.38 & -0.76 & 1.71 \\
\hline Ln(Fisher_Structural) & Natural logarithm of the Fisher Structural Index & 0.02 & 0.13 & -0.43 & 0.44 \\
\hline Ln(EPI) & $\begin{array}{l}\text { Natural logarithm of weighted average energy prices } \\
\text { (1995 USD/toe) }\end{array}$ & 6.78 & 0.14 & 6.08 & 7.12 \\
\hline Ln(GNI_CAP & Natuarl logarithm of GNI per capita (1995 USD) & 9.2 & 1.16 & 5.94 & 11.06 \\
\hline $\begin{array}{l}\text { Ln(Inv_K) } \\
\text { Ln(TDD) }\end{array}$ & Natural logarithm of investment to capital ratio & -2.76 & 0.44 & -5.36 & -1.84 \\
\hline $\begin{array}{l}\text { Ln(Industry) } \\
\text { Natural logarithm of total degree days }\end{array}$ & Natural logarithm of industry value added as a \% of GDP & 3.41 & 1.93 & 2.52 & 3.93 \\
\hline $\begin{array}{l}\text { Table 4: Summary statistics for dependent and independent variables. } \\
\text { Source: KAPSARC }\end{array}$ & & & & & 7.63 \\
\hline
\end{tabular}

\begin{tabular}{|c|c|c|c|c|c|c|}
\hline \multirow[b]{2}{*}{ Independent Variable } & \multicolumn{2}{|c|}{ DLOG(Fisher_Aggregate_EP) } & \multicolumn{2}{|c|}{ DLOG(Fisher_Sectoral_EP) } & \multicolumn{2}{|c|}{ DLOG(Fisher_Structural) } \\
\hline & Coefficient & std. error & Coefficient & std. error & Coefficient & std. error \\
\hline DLOG(dependent variable, 2 & $-0.174^{* * *}$ & 0.045 & $-0.191^{* \star \star}$ & 0.045 & 0.067 & 0.050 \\
\hline DLOG(dependent variable, 1 lag) & -0.054 & 0.051 & -0.032 & 0.051 & $0.154^{* * *}$ & 0.049 \\
\hline DLOG(GNI_CAP, 2 lags) & -0.048 & 0.073 & -0.098 & 0.077 & 0.042 & 0.042 \\
\hline DLOG(GNI_CAP, 1 lag) & $-0.301^{* * *}$ & 0.090 & $-0.261^{* * *}$ & 0.094 & -0.052 & 0.049 \\
\hline DLOG(GNI_CAP) & $1.153^{* * *}$ & 0.068 & $1.122^{* * *}$ & 0.073 & 0.026 & 0.041 \\
\hline DLOG(INV_CAP, 2 lags) & $0.113^{* *}$ & 0.048 & 0.069 & 0.051 & 0.021 & 0.029 \\
\hline DLOG(INV_CAP, 1 lag) & 0.049 & 0.049 & 0.033 & 0.052 & -0.015 & 0.030 \\
\hline DLOG(INV_CAP) & 0.002 & 0.046 & $-0.118^{* *}$ & 0.049 & $0.112^{* * *}$ & 0.028 \\
\hline DLOG(INDUSTRY, 2 lags) & -0.027 & 0.089 & -0.108 & 0.095 & $0.110^{* *}$ & 0.054 \\
\hline DLOG(INDUSTRY, 1 lag) & 0.058 & 0.083 & 0.144 & 0.090 & -0.055 & 0.050 \\
\hline DLOG(INDUSTRY) & $-0.194^{* *}$ & 0.079 & -0.070 & 0.084 & $-0.091^{*}$ & 0.048 \\
\hline DLOG(EPI, 2 lags) & 0.248 & 0.171 & $0.342 *$ & 0.183 & -0.084 & 0.104 \\
\hline DLOG(EPI, 1 lag) & -0.064 & 0.180 & 0.019 & 0.193 & -0.045 & 0.108 \\
\hline DLOG(EPI) & $0.687^{* * *}$ & 0.177 & $0.752^{* * *}$ & 0.190 & -0.049 & 0.108 \\
\hline DLOG(TDD, 2 lags) & -0.107 & 0.067 & 0.009 & 0.072 & $-0.093^{* *}$ & 0.041 \\
\hline DLOG(TDD, 1 lag) & -0.062 & 0.078 & -0.003 & 0.083 & -0.029 & 0.047 \\
\hline DLOG(TDD) & -0.159 ** & 0.072 & -0.059 & 0.076 & $-0.081^{*}$ & 0.044 \\
\hline$e_{t-1}$ & $-0.328^{* * *}$ & 0.047 & $-0.347^{* \star *}$ & 0.049 & $-0.320^{* * *}$ & 0.035 \\
\hline Intercept & 0.001 & 0.005 & 0.009 * & 0.005 & -0.004 & 0.003 \\
\hline R-squared & 0.729 & & 0.704 & & 0.311 & \\
\hline Durbin-Watson statistic & 1.882 & & 1.912 & & 1.926 & \\
\hline Akaike info criterion & -2.541 & & -2.400 & & -3.528 & \\
\hline Schwarz criterion & -2.275 & & -2.134 & & -3.262 & \\
\hline
\end{tabular}


intuitive given that these two factors typically lead to greater relative energy consumption. The industry's share of GDP results also aligns with the decomposition findings that increasing levels of industrial output are a drag on energy productivity.

Fisher Sectoral Energy Productivity regressions deliver similar conclusions. The same 2-year lagged negative impact of the dependent variable is seen, which may reflect energy productivity convergence and a general deceleration in the rate of energy productivity improvements.

Increasing prices drive rationalization of consumption patterns and adoption of more efficient technologies and behaviors.

Higher energy prices are associated with increases in aggregate energy productivity predominantly through the sectoral energy productivity channel, as a $1 \%$ increase in growth rate of energy prices is associated with a $0.76 \%$ point increase in sectoral energy productivity. A 2-year lag in energy price growth rates is also significant at the $10 \%$ level. Higher growth rates of income per capita are also associated with the sectoral energy productivity effect at the $1 \%$ significance level, although the 1-year lag is a slight drag on sectoral energy productivity.

The investment to capital ratio proved to apply downward pressure on sectoral energy productivity at the $5 \%$ significance level. This contradicts the finding in the aggregate energy productivity regression of a positive effect from the 2-year lag in the investment to capital ratio. The short-run response in the sectoral regression may be indicative of the additional energy required to construct or develop new infrastructure and technologies, while the benefits of the newly deployed capital are not realized until later years.

For the Fisher Structural Index regression, the 1-year lag shows a positive response, which reinforces the suggestion of a dynamic relationship between current and past values of an economy's structure. As expected, a higher growth rate in the industry's share of total output yields a negative response in energy productivity through the sectoral effect. Interestingly, a 2-year lag in the industry variable elicits a statistically significant positive response in the structural effect. This perhaps suggests a feedback between industrial growth and services growth as industries require more support and financial services as they grow. Alternatively, the 2-year lagged positive response may be due to cyclical growth in industrial sectors.

The negative impact of high TDD is significant at the $10 \%$ significance level and suggests economies in more extreme climates are industry-oriented. This may, however, be a geographic coincidence rather than a potential causal relationship. Moreover, our analysis is limited to industrial and commercial sectors, and temperature extremes predominantly induce large energy consumption responses from the residential sector.

Unlike the negative association in the regression for sectoral energy productivity, the structural effect regression has a positive association with higher growth rates of investment to capital ratio. A $1 \%$ increase in growth rate of investment to capital ratio is associated with a $0.112 \%$ point increase in the structural effect. This suggests higher levels of investment are boosting gross output growth in energy productive sectors like services and advanced manufacturing, more so than in energy intensive sectors. 


\section{Conclusions}

Results from the three analyses reveal several key findings that deepen the understanding of the determinants of energy productivity improvements. First, the decomposition analysis shows sectoral energy productivity increases from 1995-2009 are primarily responsible for economy-wide improvements. This should alleviate concerns that countries are becoming more energy productive due to structural economic shifts (offshoring of their energy intensive industries) and growth in service sectors.

Second, countries with similar demographic and economic characteristics have similar energy productivity levels and annualized rates of improvement. Most notably, the cluster analysis shows nations that liberalized their economies during the period-such as the Eastern European nations-improved at faster rates, while BRIC nations and other large industrializing economies lagged behind despite having similar energy productivity levels. The Eastern European countries have, on average, higher urbanization rates, GNI per capita, female participation rates, energy prices, and their energy imports are perceived as less secure than other emerging economies. These characteristics and others can influence economic output and energy consumption levels, and thus energy productivity.

Third, the econometric analysis results reinforce long-standing hypotheses that higher energy prices and income per capita are associated with aggregate energy productivity improvements. The analysis shows these improvements occur primarily through the sectoral energy productivity effect channel rather than shifts in the structure of the economy. Higher levels of investment are also associated with aggregate energy productivity improvements, although the response from the investments may take a few years to materialize. In the short-term, the investments can decrease sectoral energy productivity because of increased activity that does not yet generate value, but can cause the structure of the economy to shift towards more services and advanced manufacturing.

Sectoral energy productivity increases are primarily responsible for economy-wide improvements.

Policymakers will benefit from an understanding of the determinants, or underlying drivers, in their efforts to boost energy productivity. Policy that seeks to act on factors with limited impact on changes in energy productivity will likely not yield results as effectively as those that concentrate in areas that can make the most difference. This paper takes a global approach, but the determinants of energy productivity vary by country and region. Expanding data collection efforts to cover more sectoral and granular information will allow for more detailed country-specific assessments and tailored policy efforts. 
Appendix 1 - Additional results

\section{Determinants of Energy Productivity: A comparison of 39 countries}

\begin{tabular}{|c|c|c|c|c|c|c|}
\hline Sector & $\begin{array}{l}\text { Measure } \\
\text { Values }\end{array}$ & $\begin{array}{l}\text { Median Energy } \\
\text { Productivity } \\
1995-2009 \\
(95 \$ / T J)\end{array}$ & $\begin{array}{l}\text { Average } \\
\text { Coefficient } \\
\text { of Variation } \\
1995-2009\end{array}$ & $\begin{array}{l}\text { Energy } \\
\text { Productivity } \\
\text { Geometric Mean } \\
\text { Growth Rate } \\
\text { 1995-2009 }\end{array}$ & $\begin{array}{l}\text { Share of } \\
\text { Total } \\
\text { Gross } \\
\text { Output in } \\
\text { WIOD }\end{array}$ & $\begin{array}{l}\text { Share of Total } \\
\text { Energy } \\
\text { Consumption } \\
\text { in WIOD }\end{array}$ \\
\hline Financial Intermediation & $\$ 2,099,987.85$ & $\$ 2,386,730.45$ & 0.67 & $3.1 \%$ & $5.8 \%$ & $0.5 \%$ \\
\hline Real Estate Activities & $\$ 1,789,078.59$ & $\$ 3,268,893.38$ & 15.06 & $2.4 \%$ & $6.7 \%$ & $0.7 \%$ \\
\hline Electrical and Optical Equipment & $\$ 1,150,806.93$ & $\$ 1,175,130.28$ & 0.80 & $2.8 \%$ & $3.7 \%$ & $0.6 \%$ \\
\hline Renting of M\&Eq & $\$ 1,098,186.31$ & $\$ 1,219,415.58$ & 0.94 & $2.3 \%$ & $8.0 \%$ & $1.4 \%$ \\
\hline Construction & $\$ 1,032,463.58$ & $\$ 1,153,874.53$ & 1.00 & $2.0 \%$ & $7.0 \%$ & $1.3 \%$ \\
\hline Transport Equipment & $\$ 1,009,506.15$ & $\$ 951,199.90$ & 0.67 & $0.2 \%$ & $3.8 \%$ & $0.7 \%$ \\
\hline Wholesale Trade & $\$ 965,171.48$ & $\$ 936,540.71$ & 0.71 & $2.4 \%$ & $4.9 \%$ & $0.9 \%$ \\
\hline Sale \& Maintenance of Motor Vehicles & $\$ 962,520.34$ & $\$ 807,759.40$ & 0.54 & $0.9 \%$ & $1.2 \%$ & $0.2 \%$ \\
\hline Post and Telecommunications & $\$ 764,836.81$ & $\$ \quad 832,288.11$ & 1.12 & $1.1 \%$ & $2.1 \%$ & $0.5 \%$ \\
\hline Health and Social Work & $\$ 747,887.03$ & $\$ 830,747.55$ & 0.66 & $2.1 \%$ & $4.5 \%$ & $1.1 \%$ \\
\hline Machinery, Nec & $\$ 704,666.73$ & $\$ \quad 837,296.22$ & 1.00 & $3.0 \%$ & $2.4 \%$ & $0.6 \%$ \\
\hline Leather and Footwear & $\$ 648,113.71$ & $\$ \quad 593,592.38$ & 0.78 & $3.2 \%$ & $0.3 \%$ & $0.1 \%$ \\
\hline Manufacturing, Nec; Recycling & $\$ 622,646.38$ & $\$ \quad 645,939.79$ & 0.80 & $2.6 \%$ & $0.8 \%$ & $0.2 \%$ \\
\hline Education & $\$ 574,938.86$ & $\$ 706,731.96$ & 0.90 & $0.9 \%$ & $2.1 \%$ & $0.7 \%$ \\
\hline Other Social and Personal Services & $\$ 514,107.08$ & $\$ \quad 553,871.10$ & 0.65 & $2.1 \%$ & $3.4 \%$ & $1.2 \%$ \\
\hline Retail Trade & $\$ 513,334.67$ & $\$ \quad 603,248.62$ & 0.66 & $1.8 \%$ & $4.1 \%$ & $1.5 \%$ \\
\hline Rubber and Plastics & $\$ 443,461.03$ & $\$ \quad 498,508.24$ & 1.43 & $1.8 \%$ & $1.2 \%$ & $0.5 \%$ \\
\hline Hotels and Restaurants & $\$ 429,197.24$ & $\$ \quad 560,280.79$ & 0.97 & $0.9 \%$ & $2.8 \%$ & $1.2 \%$ \\
\hline Public Admin and Defense & $\$ 399,784.55$ & $\$ 720,918.10$ & 1.63 & $3.8 \%$ & $6.3 \%$ & $3.0 \%$ \\
\hline Other Transport Activities & $\$ 367,340.41$ & $\$ \quad 484,820.03$ & 1.76 & $-0.5 \%$ & $1.2 \%$ & $0.6 \%$ \\
\hline Food, Beverages and Tobacco & $\$ 321,004.13$ & $\$ \quad 440,709.39$ & 0.74 & $0.7 \%$ & $4.1 \%$ & $2.4 \%$ \\
\hline Textiles and Textile Products & $\$ 277,343.74$ & $\$ 380,133.08$ & 0.79 & $1.6 \%$ & $1.4 \%$ & $0.9 \%$ \\
\hline Agriculture, Hunting, Forestry and Fishing & $\$ 196,241.68$ & $\$ \quad 230,683.27$ & 1.63 & $2.6 \%$ & $2.9 \%$ & $2.7 \%$ \\
\hline Wood and Wood Products & $\$ 174,036.91$ & $\$ \quad 227,481.63$ & 1.54 & $2.0 \%$ & $0.6 \%$ & $0.7 \%$ \\
\hline Pulp, Paper and Publishing & $\$ 156,472.05$ & $\$ \quad 205,884.19$ & 4.85 & $-0.5 \%$ & $1.9 \%$ & $2.3 \%$ \\
\hline Chemicals and Chemical Products & $\$ 128,164.86$ & $\$ \quad 169,101.72$ & 2.54 & $2.9 \%$ & $3.0 \%$ & $4.3 \%$ \\
\hline Inland Transport & $\$ 123,780.37$ & $\$ \quad 134,158.75$ & 0.81 & $1.1 \%$ & $2.4 \%$ & $3.6 \%$ \\
\hline Basic Metals and Fabricated Metal & $\$ 116,782.68$ & $\$ 154,140.14$ & 2.23 & $1.2 \%$ & $4.0 \%$ & $6.3 \%$ \\
\hline Coke and Refined Products & $\$ \quad 85,748.60$ & $99,863.87$ & 12.65 & $6.0 \%$ & $1.7 \%$ & $3.7 \%$ \\
\hline Mining and Quarrying & $\$ 79,462.40$ & $\$ 124,534.54$ & 1.89 & $3.8 \%$ & $1.5 \%$ & $3.5 \%$ \\
\hline Other Non-Metallic Mineral & $\$ \quad 63,283.84$ & $\$ \quad 77,624.13$ & 2.36 & $-0.3 \%$ & $1.0 \%$ & $3.1 \%$ \\
\hline Water Transport & $\$ \quad 44,818.00$ & $42,497.39$ & 16.62 & $1.7 \%$ & $0.4 \%$ & $1.6 \%$ \\
\hline Air Transport & $\$ \quad 44,543.25$ & $43,713.06$ & 1.63 & $0.7 \%$ & $0.5 \%$ & $2.2 \%$ \\
\hline Electricity, Gas and Water Supply & $\$ \quad 9,925.74$ & $11,144.89$ & 1.52 & $0.9 \%$ & $2.4 \%$ & $45.2 \%$ \\
\hline
\end{tabular}




\begin{tabular}{|c|c|c|c|c|c|c|}
\hline Country & $\begin{array}{l}\text { Weighted Average } \\
\text { Energy } \\
\text { Productivity } \\
\text { 1995-2009 } \\
\text { (95\$/TJ) }\end{array}$ & $\begin{array}{l}\text { Energy } \\
\text { Productivity } \\
\text { Geometric Mean } \\
\text { Growth Rate } \\
\text { 1995-2009 }\end{array}$ & $\begin{array}{l}\text { Energy } \\
\text { Consumption } \\
\text { Geometric Mean } \\
\text { Growth Rate } \\
\text { 1995-2009 }\end{array}$ & $\begin{array}{l}\text { Gross Output } \\
\text { Geometric Mean } \\
\text { Growth Rate } \\
1995-2009\end{array}$ & $\begin{array}{l}\text { Share of Energy } \\
\text { Consumption in } \\
\text { WIOD } \\
1995-2009\end{array}$ & $\begin{array}{l}\text { Share of Gross } \\
\text { Output in WIOD } \\
\text { 1995-2009 }\end{array}$ \\
\hline Ireland & $\$ 511,118$ & $4.08 \%$ & $3.13 \%$ & $7.35 \%$ & $0.17 \%$ & $0.46 \%$ \\
\hline Luxembourg & $\$ 446,579$ & $2.30 \%$ & $5.15 \%$ & $7.57 \%$ & $0.05 \%$ & $0.11 \%$ \\
\hline Austria & $\$ 419,495$ & $0.69 \%$ & $1.57 \%$ & $2.27 \%$ & $0.32 \%$ & $0.72 \%$ \\
\hline Italy & $\$ 415,715$ & $1.94 \%$ & $0.68 \%$ & $2.63 \%$ & $1.98 \%$ & $4.41 \%$ \\
\hline United Kingdom & $\$ 376,255$ & $3.03 \%$ & $-0.40 \%$ & $2.62 \%$ & $2.49 \%$ & $5.03 \%$ \\
\hline Japan & $\$ 348,132$ & $-1.97 \%$ & $-0.39 \%$ & $-2.35 \%$ & $6.93 \%$ & $12.94 \%$ \\
\hline Spain & $\$ 318,147$ & $2.52 \%$ & $2.23 \%$ & $4.80 \%$ & $1.54 \%$ & $2.63 \%$ \\
\hline Germany & $\$ 304,973$ & $0.53 \%$ & $-0.26 \%$ & $0.28 \%$ & $4.21 \%$ & $6.89 \%$ \\
\hline Belgium & $\$ 298,486$ & $1.30 \%$ & $0.57 \%$ & $1.88 \%$ & $0.64 \%$ & $1.03 \%$ \\
\hline France & $\$ 290,433$ & $1.53 \%$ & $0.37 \%$ & $1.91 \%$ & $3.22 \%$ & $5.02 \%$ \\
\hline Portugal & $\$ 283,772$ & $0.97 \%$ & $2.09 \%$ & $3.08 \%$ & $0.29 \%$ & $0.44 \%$ \\
\hline Denmark & $\$ 279,676$ & $0.43 \%$ & $1.93 \%$ & $2.37 \%$ & $0.38 \%$ & $0.57 \%$ \\
\hline Netherlands & $\$ 247,784$ & $3.75 \%$ & $-0.98 \%$ & $2.73 \%$ & $1.16 \%$ & $1.55 \%$ \\
\hline Sweden & $\$ 220,912$ & $2.04 \%$ & $-0.50 \%$ & $1.52 \%$ & $0.76 \%$ & $0.90 \%$ \\
\hline Greece & $\$ 219,036$ & $1.06 \%$ & $2.87 \%$ & $3.96 \%$ & $0.39 \%$ & $0.46 \%$ \\
\hline Turkey & $\$ 207,743$ & $1.14 \%$ & $4.59 \%$ & $5.78 \%$ & $0.91 \%$ & $1.02 \%$ \\
\hline Australia & $\$ 207,638$ & $2.28 \%$ & $2.63 \%$ & $4.97 \%$ & $1.55 \%$ & $1.72 \%$ \\
\hline USA & $\$ 201,957$ & $2.23 \%$ & $0.13 \%$ & $2.37 \%$ & $27.63 \%$ & $29.93 \%$ \\
\hline Slovenia & $\$ 198,096$ & $2.66 \%$ & $1.58 \%$ & $4.28 \%$ & $0.08 \%$ & $0.09 \%$ \\
\hline Brazil & $\$ 187,814$ & $0.09 \%$ & $3.49 \%$ & $3.59 \%$ & $2.28 \%$ & $2.29 \%$ \\
\hline Cyprus & $\$ 185,255$ & $2.20 \%$ & $2.98 \%$ & $5.25 \%$ & $0.03 \%$ & $0.03 \%$ \\
\hline Mexico & $\$ 182,956$ & $2.39 \%$ & $2.54 \%$ & $4.99 \%$ & $1.78 \%$ & $1.75 \%$ \\
\hline Finland & $\$ 182,353$ & $1.48 \%$ & $1.32 \%$ & $2.82 \%$ & $0.50 \%$ & $0.49 \%$ \\
\hline South Korea & $\$ 167,230$ & $-1.03 \%$ & $3.61 \%$ & $2.53 \%$ & $2.52 \%$ & $2.26 \%$ \\
\hline Hungary & $\$ 161,641$ & $5.95 \%$ & $-0.21 \%$ & $5.73 \%$ & $0.29 \%$ & $0.26 \%$ \\
\hline Latvia & $\$ 143,839$ & $11.91 \%$ & $-0.95 \%$ & $10.84 \%$ & $0.05 \%$ & $0.04 \%$ \\
\hline Canada & $\$ 138,343$ & $3.55 \%$ & $0.55 \%$ & $4.12 \%$ & $3.33 \%$ & $2.47 \%$ \\
\hline Malta & $\$ 131,387$ & $3.59 \%$ & $0.55 \%$ & $4.17 \%$ & $0.02 \%$ & $0.01 \%$ \\
\hline Czech Republic & $\$ 125,832$ & $6.94 \%$ & $0.16 \%$ & $7.12 \%$ & $0.56 \%$ & $0.38 \%$ \\
\hline Poland & $\$ 117,399$ & $6.93 \%$ & $-0.25 \%$ & $6.66 \%$ & $1.20 \%$ & $0.76 \%$ \\
\hline Slovak Republic & $\$ 113,010$ & $9.27 \%$ & $-0.45 \%$ & $8.78 \%$ & $0.23 \%$ & $0.14 \%$ \\
\hline Indonesia & $\$ 111,536$ & $-0.47 \%$ & $4.60 \%$ & $4.10 \%$ & $1.39 \%$ & $0.83 \%$ \\
\hline China & $\$ 95,736$ & $6.54 \%$ & $6.74 \%$ & $13.72 \%$ & $16.29 \%$ & $8.37 \%$ \\
\hline Estonia & $\$ 87,842$ & $9.26 \%$ & $-0.13 \%$ & $9.12 \%$ & $0.07 \%$ & $0.03 \%$ \\
\hline Romania & $\$ 86,238$ & $11.55 \%$ & $-3.12 \%$ & $8.06 \%$ & $0.49 \%$ & $0.23 \%$ \\
\hline Lithuania & $\$ 81,942$ & $10.59 \%$ & $-0.73 \%$ & $9.78 \%$ & $0.12 \%$ & $0.05 \%$ \\
\hline India & $\$ 77,730$ & $1.99 \%$ & $5.21 \%$ & $7.31 \%$ & $4.78 \%$ & $1.99 \%$ \\
\hline Bulgaria & $\$ 48,804$ & $9.43 \%$ & $-1.59 \%$ & $7.69 \%$ & $0.28 \%$ & $0.07 \%$ \\
\hline Russia & $\$ 33,438$ & $7.43 \%$ & $-0.08 \%$ & $7.34 \%$ & $9.08 \%$ & $1.63 \%$ \\
\hline
\end{tabular}




\begin{tabular}{|c|c|c|c|c|c|c|c|c|c|}
\hline & \multicolumn{3}{|c|}{2000} & \multicolumn{3}{|c|}{2005} & \multicolumn{3}{|c|}{2009} \\
\hline & $\begin{array}{l}\text { Structural } \\
\text { Index }\end{array}$ & $\begin{array}{l}\text { Sectoral } \\
\text { Energy } \\
\text { Productivity } \\
\text { Index }\end{array}$ & $\begin{array}{l}\text { Aggregate } \\
\text { Energy } \\
\text { Productivity } \\
\text { Index }\end{array}$ & $\begin{array}{l}\text { Structural } \\
\text { Index }\end{array}$ & $\begin{array}{l}\text { Sectoral } \\
\text { Energy } \\
\text { Productivity } \\
\text { Index }\end{array}$ & $\begin{array}{l}\text { Aggregate } \\
\text { Energy } \\
\text { Productivity } \\
\text { Index }\end{array}$ & $\begin{array}{l}\text { Structural } \\
\text { Index }\end{array}$ & $\begin{array}{l}\text { Sectoral } \\
\text { Energy } \\
\text { Productivity } \\
\text { Index }\end{array}$ & $\begin{array}{l}\text { Aggregate } \\
\text { Energy } \\
\text { Productivity } \\
\text { Index }\end{array}$ \\
\hline Australia & 1.02 & 0.78 & 0.80 & 1.03 & 1.06 & 1.10 & 1.09 & 1.26 & 1.37 \\
\hline Austria & 1.04 & 0.71 & 0.74 & 0.96 & 0.98 & 0.94 & 0.88 & 1.25 & 1.10 \\
\hline Belgium & 1.03 & 0.70 & 0.72 & 1.11 & 0.96 & 1.06 & 1.09 & 1.10 & 1.20 \\
\hline Brazil & 0.87 & 1.23 & 1.07 & 1.03 & 2.00 & 2.06 & 1.11 & 3.18 & 3.53 \\
\hline Bulgaria & 0.91 & 0.73 & 0.66 & 0.85 & 0.84 & 0.71 & 0.92 & 1.10 & 1.01 \\
\hline Canada & 1.05 & 1.06 & 1.11 & 1.04 & 1.40 & 1.46 & 1.07 & 1.52 & 1.63 \\
\hline China & 0.95 & 1.47 & 1.40 & 0.75 & 2.04 & 1.54 & 0.83 & 2.94 & 2.43 \\
\hline Cyprus & 0.89 & 0.88 & 0.78 & 0.97 & 1.14 & 1.11 & 1.01 & 1.34 & 1.36 \\
\hline Czech Republic & 1.17 & 0.86 & 1.00 & 1.33 & 1.38 & 1.84 & 1.33 & 1.92 & 2.56 \\
\hline Denmark & 0.92 & 0.85 & 0.78 & 0.87 & 1.12 & 0.98 & 0.90 & 1.18 & 1.06 \\
\hline Estonia & 1.25 & 1.22 & 1.53 & 1.40 & 1.99 & 2.78 & 1.12 & 3.09 & 3.45 \\
\hline Finland & 1.20 & 0.67 & 0.80 & 1.22 & 0.89 & 1.08 & 1.17 & 1.05 & 1.23 \\
\hline France & 1.09 & 0.72 & 0.78 & 1.02 & 1.03 & 1.05 & 0.99 & 1.28 & 1.27 \\
\hline Germany & 1.06 & 0.70 & 0.74 & 0.92 & 1.02 & 0.94 & 0.85 & 1.26 & 1.08 \\
\hline Greece & 0.92 & 0.75 & 0.69 & 0.78 & 1.20 & 0.94 & 0.83 & 1.40 & 1.16 \\
\hline Hungary & 1.12 & 0.92 & 1.02 & 1.07 & 1.84 & 1.97 & 0.98 & 2.29 & 2.25 \\
\hline India & 0.76 & 0.69 & 0.52 & 0.67 & 0.89 & 0.60 & 0.74 & 1.26 & 0.94 \\
\hline Indonesia & 1.06 & 0.87 & 0.92 & 1.16 & 1.05 & 1.21 & 1.23 & 1.07 & 1.32 \\
\hline Ireland & 1.42 & 0.75 & 1.07 & 1.37 & 1.22 & 1.67 & 1.22 & 1.43 & 1.75 \\
\hline Italy & 0.98 & 0.89 & 0.87 & 0.97 & 1.16 & 1.13 & 0.96 & 1.37 & 1.31 \\
\hline Japn & 1.01 & 0.78 & 0.78 & 1.00 & 0.70 & 0.70 & 0.95 & 0.80 & 0.76 \\
\hline Latvia & 1.08 & 1.73 & 1.87 & 1.20 & 2.65 & 3.19 & 0.99 & 4.87 & 4.83 \\
\hline Lithuania & 1.44 & 1.23 & 1.78 & 1.31 & 2.37 & 3.11 & 1.30 & 3.15 & 4.09 \\
\hline Luxembourg & 1.17 & 0.75 & 0.88 & 1.22 & 0.84 & 1.03 & 1.44 & 0.95 & 1.37 \\
\hline Malta & 0.95 & 1.23 & 1.17 & 0.85 & 1.52 & 1.30 & 0.86 & 1.90 & 1.64 \\
\hline Mexico & 0.98 & 1.47 & 1.44 & 0.84 & 1.80 & 1.52 & 0.87 & 1.60 & 1.39 \\
\hline Netherlands & 0.98 & 0.87 & 0.86 & 0.92 & 1.33 & 1.22 & 0.94 & 1.79 & 1.67 \\
\hline Poland & 1.15 & 1.08 & 1.24 & 1.08 & 1.80 & 1.93 & 1.07 & 2.39 & 2.56 \\
\hline Portugal & 1.06 & 0.69 & 0.73 & 1.00 & 0.96 & 0.96 & 0.95 & 1.20 & 1.14 \\
\hline Romania & 1.03 & 1.14 & 1.18 & 1.09 & 2.44 & 2.65 & 1.17 & 3.96 & 4.62 \\
\hline Russia & 1.16 & 0.62 & 0.72 & 1.09 & 1.60 & 1.74 & 1.12 & 2.44 & 2.73 \\
\hline Slovak & 1.09 & 0.94 & 1.02 & 1.07 & 1.68 & 1.80 & 1.06 & 3.27 & 3.46 \\
\hline Slovenia & 1.10 & 0.74 & 0.81 & 1.06 & 1.07 & 1.14 & 0.99 & 1.46 & 1.44 \\
\hline South Korea & 0.91 & 0.82 & 0.74 & 0.90 & 1.04 & 0.94 & 0.86 & 1.01 & 0.86 \\
\hline Spain & 1.17 & 0.81 & 0.96 & 1.07 & 1.10 & 1.18 & 1.02 & 1.30 & 1.33 \\
\hline Sweden & 1.05 & 0.69 & 0.72 & 1.04 & 1.02 & 1.06 & 0.96 & 1.47 & 1.42 \\
\hline Turkey & 0.92 & 0.97 & 0.89 & 0.88 & 1.36 & 1.20 & 0.82 & 1.43 & 1.17 \\
\hline United & 1.12 & 0.99 & 1.11 & 1.11 & 1.39 & 1.53 & 1.15 & 1.32 & 1.52 \\
\hline United States & 0.98 & 1.16 & 1.14 & 1.03 & 1.26 & 1.30 & 1.08 & 1.26 & 1.36 \\
\hline
\end{tabular}




\section{Appendix 2 - Data, methodologies and references}

\section{Determinants of energy productivity: A comparison of 39 countries}

Understanding the drivers of economy-wide energy productivity changes can inform energy policy. KAPSARC decomposed energy productivity changes occurring between 1995 and 2009 for 39 countries to investigate the main drivers of change. A cluster analysis and econometric analysis were also used to explore potential associations of demographic and economic characteristics with energy productivity performance of countries.

This appendix describes the data, analytical methodologies, and supplemental findings of the study. The first section describes the dataset used for the decomposition analysis. The second section reviews the decomposition analysis approach. Variables used in the cluster and econometric analyses are described in the third section. The cluster analysis methodology and econometric analysis approach are described in the fourth and fifth section, respectively.

\section{Dataset}

Our analysis is based on a time-series of sectoral gross output and energy consumption data for 39 countries from the World Input Output Database (WIOD) (Timmer, 2012). Each country is disaggregated to 34 commercial and industrial sectors (Table 9). The residential sector was excluded at this stage of the research. Key developed and emerging economies are included in the dataset, and in total, the 39 countries account for nearly $85 \%$ of global GDP and $80 \%$ of energy consumption.

Gross output data for all countries in WIOD are in 2014 US dollars which we converted to 1995 US dollars using the US GDP price deflator. Although evaluating energy productivity in purchasing power parity (PPP) terms may be more desirable, we did not do so because sectoral PPP conversions are not available for the 34 commercial and industry sectors. Taiwan was excluded from our dataset because several variables in our cluster and econometric analysis were not readily available. Gross output data for France's "Electricity, Gas and Water Supply" sector was updated using UNSTATS data because of an apparent error in the WIOD.

Voigt et al. (2014) also used the WIOD to investigate energy intensity developments occurring in 40 countries between 1995-2007. The WIOD includes two energy datasets, and our choice of WIOD energy dataset results in a substantial difference from Voigt et al. (2014).

We use the "Emissions Relevant Energy Use" dataset, which aligns with total primary energy supply as reported in the International Energy Agency's Energy Balances and excludes energy used as a feedstock. Voigt et al. (2014) uses WIOD's "Energy Use" dataset that is directly related to expenditures for energy inputs and includes non-energy (feedstock) use. Their accounting for energy in this fashion results in some double counting as noted in Timmer (2012), such as crude oil as an input for the refining sector and the subsequent refined products as inputs to all other sectors, and makes countries appear less energy productive. 


\section{WIOD Sector Naming Convention}

Agriculture, Hunting, Forestry and Fishing

Mining and Quarrying

Food, Beverages and Tobacco

Textiles and Textile Products

Leather, Leather and Footwear

Wood and Products of Wood and Cork

Pulp, Paper, Paper , Printing and Publishing

Coke, Refined Petroleum and Nuclear Fuel

Chemicals and Chemical Products

Rubber and Plastics

Other Non-Metallic Mineral

Basic Metals and Fabricated Metal

Machinery, Nec

Electrical and Optical Equipment

Transport Equipment

Manufacturing, Nec; Recycling

Electricity, Gas and Water Supply

Construction

Sale, Maintenance and Repair of Motor Vehicles and Motorcycles; Retail Sale of Fuel Wholesale Trade and Commission Trade, Except of Motor Vehicles and Motorcycles

Retail Trade, Except of Motor Vehicles and Motorcycles; Repair of Household Goods

Hotels and Restaurants

Inland Transport

Water Transport

Air Transport

Other Supporting and Auxiliary Transport Activities; Activities of Travel Agencies

Post and Telecommunications

Financial Intermediation

Real Estate Activities

Renting of M\&Eq and Other Business Activities

Public Admin and Defence; Compulsory Social Security

Education

Health and Social Work

Other Community, Social and Personal Services
Truncated Naming Convention

Agriculture, Hunting, Forestry and Fishing

Mining and Quarrying

Food, Beverages and Tobacco

Textiles

Leather and Footwear

Wood and Wood Products

Pulp, Paper and Publishing

Coke and Refined Products

Chemicals and Chemical Products

Rubber and Plastics

Other Non-Metallic Mineral

Basic Metals and Fabricated Metal

Machinery, Nec

Electrical and Optical Equipment

Transport Equipment

Manufacturing, Nec; Recycling

Electricity, Gas and Water Supply

Construction

Sale and Maintenance of Motor Vehicles

Wholesale Trade

Retail Trade

Hotels and Restaurants

Inland Transport

Water Transport

Air Transport

Other Transport Activities

Post and Telecommunications

Financial Intermediation

Real Estate Activities

Renting of M\&Eq

Public Adminstration and Defense

Education

Health and Social Work

Other Social and Personal Services

Table 9: WIOD sector names and truncated naming convention.

Source: KAPSARC

The differences between the two datasets are substantial. The "Emissions Relevant Energy Use" dataset has about 34\% less total intermediate energy consumption than the "Energy Use" dataset during the study period (See Figure 5). Therefore, decomposition results in our study differ from Voigt et al. (2014) in both economywide and sectoral energy productivity indexes. The structural effects also differ despite using the same gross output data because the magnitude of the structural effect's influence on economy-wide improvements is tied to the relative energy productivity (or intensity) of each sector. Our analysis also uses data extended through 2009. 


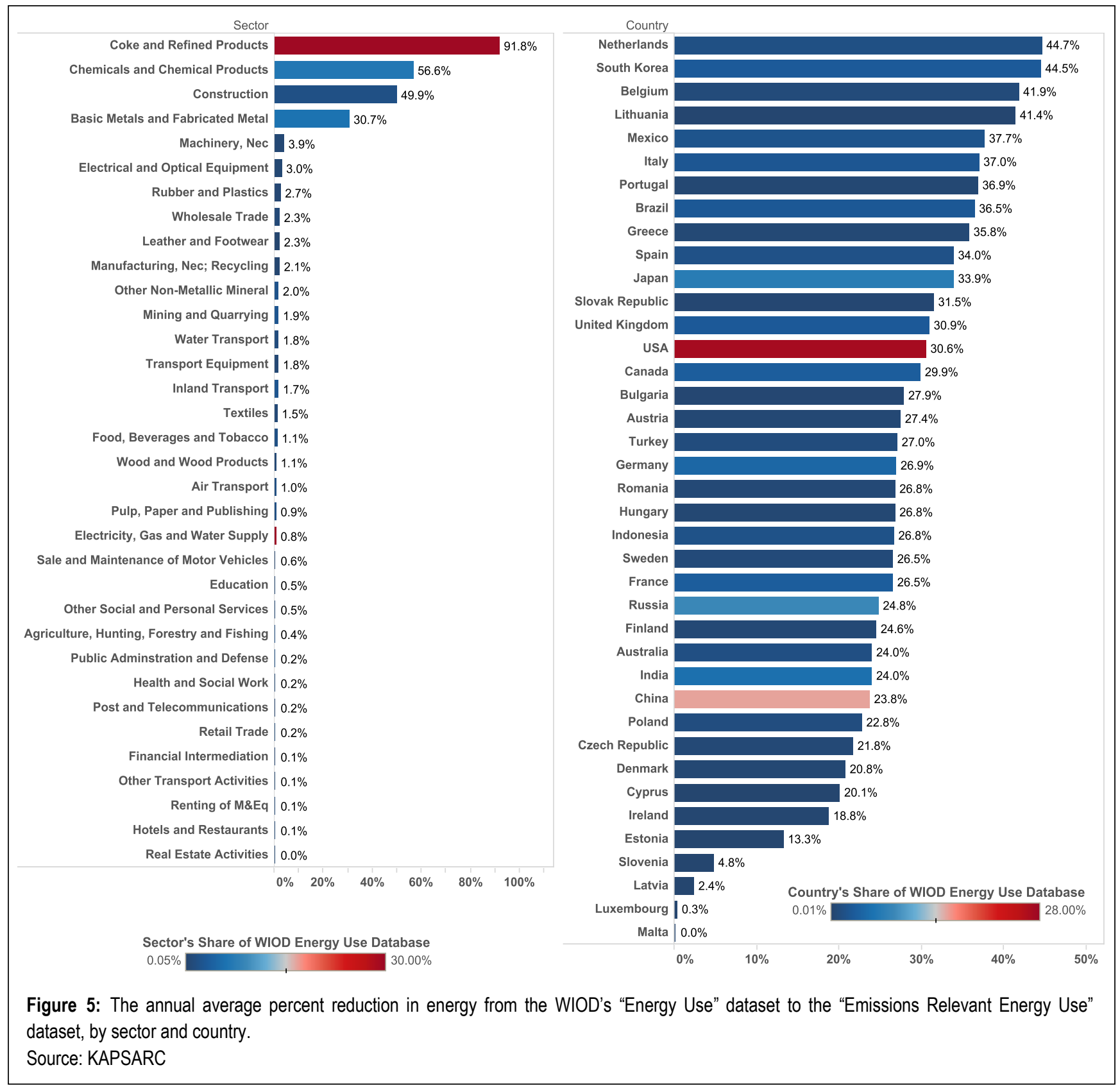

\section{Fisher Ideal Index Decomposition}

Numerous studies have decomposed aggregate energy and environmental indicators like energy intensity into various effects (see Ang and Zhang 2000 for a literature review). Decomposition analysis helps pinpoint the drivers behind the evolution of domestic energy demand, whether it is structural changes, energy efficiency improvements or other factors (Ang et al. 1998). Two commonly used methods are the Fisher Ideal Index, and the Logarithmic Mean Divisia Index (LMDI). The Fisher Ideal Index method—first applied to energy intensity changes by Boyd and Roop (2004) — and LMDI methods developed and described by Sun and Ang (2000), Ang (2004), Ang and Liu (2001 \& 2003) and Ang and Xu (2013), are favored approaches because they yield perfect decompositions without residuals. 
We use the Fisher Ideal Index method in order to remain consistent with similar research by Metcalf (2008), Song and Zheng (2012) and Jimenez and Mercado (2014). Moreover, we used the LMDI approach and found it yields similar decompositions as the Fisher Ideal Index.

Decompositions of energy productivity into sectoral and structural effects is limited, because energy productivity's structural form is incompatible with the methodology. Economy-wide energy productivity is the average energy productivity of each sector weighted by the sector's share of energy consumption. Therefore, the structural effect and sectoral energy productivity effects become conflated. To overcome this, we instead decompose energy intensity changes, and then take the reciprocal of the effects to arrive at an energy productivity decomposition.

Energy intensity is the average energy intensity of each sector weighted by its economic output and can be decomposed into the two effects. Energy intensity (et) can be written as a function of energy efficiency and economic activity components:

$$
e_{t} \equiv \frac{E_{t}}{Y_{t}}=\sum_{i}\left(\frac{E_{i t}}{Y_{i t}}\right)\left(\frac{Y_{i t}}{Y_{t}}\right)=\sum e_{i t} s_{i t}
$$

Where Et is aggregate energy consumption in year $t$, and Eit is energy consumption of sector $i$ in year $t$. Yt is aggregate economic output in year $t$ while $Y$ it is economic output in sector $i$ in year $t$. Energy intensity is a function of sector energy intensity (eit), and sectoral activity (sit is the ratio of sectoral activity to overall GDP).

For the decomposition analysis, eo is the energy intensity for a base year, and an energy intensity index is et/ eo. The Fisher Ideal Index is the geometric mean of the Laspeyres and Paasche sectoral energy intensity (s.int) and structural (stru) indexes completed for each country.

The Laspeyres indexes are:

$$
L_{t}^{s t r u}=\frac{\sum_{i} e_{i, 0} s_{i, t}}{\sum_{i} e_{i, 0} s_{i, 0}} \quad L_{t}^{s . i n t}=\frac{\sum_{i} e_{i, t} s_{i, 0}}{\sum_{i} e_{i, 0} s_{i, 0}}
$$

The Paasche indexes are:

$$
P_{t}^{s t r u}=\frac{\sum_{i} e_{i, t} S_{i, t}}{\sum_{i} e_{i, t} S_{i, 0}}
$$$$
P_{t}^{\text {s.int }}=\frac{\sum_{i} e_{i, t} S_{i, t}}{\sum_{i} e_{i, 0} S_{i, t}}
$$

The Fisher indexes are:

$$
F_{t}^{s t r u}=\sqrt{L_{t}^{s t r u} P_{t}^{s t r u}}
$$$$
F_{t}^{s . i n t}=\sqrt{L_{t}^{s-i n t} P_{t}^{s . i n t}}
$$

And the Fisher Ideal Index $\left(I_{t}\right)$ is

$$
I_{t} \equiv \frac{e_{t}}{e_{0}}=F_{t}^{s t r u} \times F_{t}^{\text {s.int }}
$$


To arrive at an energy productivity index, the reciprocal of the Fisher Sectoral Energy Intensity and Fisher Structural Index are taken. The product of the two reciprocals yields the Fisher Aggregate Energy Productivity Index, which is also the reciprocal of the Fisher Aggregate Energy Intensity index.

\section{Variables used in the cluster and econometric analysis}

Several studies investigate relationships between decomposed energy intensity effects and demographic and economic characteristics using econometric approaches. These studies include Metcalf (2008), Song and Zheng (2012), and Mercado and Jimenez (2014). Our paper expands upon their research by using an econometric analysis in addition to a cluster analysis.

The economic and demographic indicators evaluated are similar to those examined in previous studies, and we also include several additional indicators in the cluster analysis. The variables include energy prices, income per capita, degree days and others that can influence economic output and energy consumption levels, and thus energy productivity. All the variables are included in the cluster analysis, but several were omitted in the econometric analysis because of the risk of too many parameters and reducing the degrees of freedom given there are only 15 years of observations. The variables are described in the subsections below.

\section{Weighted average energy price}

Energy prices are a key component of production costs for many industries. Higher prices are expected to lead to lower energy consumption according to economic theory, and can spur the development and adoption of less energy intensive capital goods (Newell et al. 2006). An indicative energy price was developed for each country using average consumer fuel prices in their industrial, commercial and residential, and transportation sectors. Prices were calculated from a consumption-based weighted average. It is expressed in the following form:

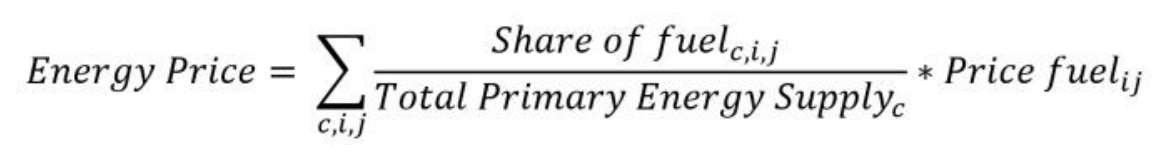

The variables $c, i$ and $j$ refer to the country, fuel type, and the sector where the fuel is consumed, respectively. As with all monetary units in this project, energy price is defined in $95 \$ /$ toe. The industrial sector includes four energy types (coke coal, natural gas, oil products and electricity), two for the residential and commercial sectors (electricity and natural gas for heating), and two for the transportation sector (diesel and gasoline).

Sector specific retail prices for each fuel come from national statistical agencies, CEIC database, Enerdata and IEA's Energy Prices and Taxes Statistics database (2013). Although limited in occurrence, some missing data points were estimated by regressing the time series to the international price of the underlying commodity or derived product. This predominantly affected industrial prices of coke coal and oil products in emerging countries. 


\section{Total degree days}

A total degree days (TDD) variable was included to account for climate differences across countries. The hypothesis is that more extreme temperatures lead to higher energy use because of greater heating and cooling requirements, and thus may be a drag on energy productivity improvements. Annual data was obtained from Atallah et al. (2014) using a reference temperature of 18.3 degrees Celsius (65 degrees Fahrenheit), and by combining cooling degree days and heating degree days at parity. Data for Cyprus, Luxembourg and Malta was obtained through Eurostat for heating degree days, and generated for CDD from Wheeler (2012).

\section{Perceived energy security index of energy imports}

The level of perceived energy security risks may spur the development and adoption of less energy-intensive practices and industries. To examine this hypothesis a perceived energy security index accounting for a country's energy mix, market power concentration, and political risk of countries it imports energy from was included. The index builds off the Energy Price Security Index suggested by IEA (2007) and Lefevre (2010) for analyzing the reliability of the sources of crude oil and natural gas imports, by including additional energy resource imports such as oil products, electricity, and coal. Our modified perceived energy security index (PESI) of imports takes the form of:

$$
\text { PESI }_{\text {import }}=\sum_{\mathrm{j}}\left[\left[\sum_{\mathrm{i}}\left(\mathrm{PR}_{\mathrm{i}} * \text { import share }_{\mathrm{ij}}\right)^{2}\right] * \frac{\text { import of fuel }_{i j}}{\mathrm{TPES}}\right]
$$

Where $P R i$ is a unitless political risk factor and "import share" and "import of fuel" are the share of each supplier $i$ and fuel $j$. The political risk is calculated using political stability and regulatory quality indicators provided by the World Bank's governance indicators on a biannual basis from 1996-2000 and annual thereafter. Together $\left(P R^{*}\right) 2$ is the political market concentration and is measured in financial terms to represent the price component of energy security rather than the physical quantity, similar to Lefevre's approach. The annual imports of fuel $j$ from country $i$ in tons of oil equivalent (TOE) are divided by total primary energy supply to quantify the share of the imported fuel in the country's energy mix. A larger value in the index reflects greater perceived energy security risks of energy imports.

The PESI of imports provides several other modifications to Lefevre's index. The political market concentration was altered by expanding the risk factor to include an indicator covering the control of corruption, and by applying the Herfindhal's concentration index on the combined product of the political risk and import/export market share. The Herfindhal Index is an indicator of market concentration and assessed by summing the squares of the market share of each firm competing in a market. Lefevre's ESI Index, on the other hand, treats political risk as a multiplicative outside the concentration index. Furthermore, the IEA considers a supplier's global share of a specific fuel, not its specific share in the local market. In contrast, our calculation of the concentration index is based on the bilateral trade relationships for each fuel between each country. This allows for a better incorporation of the political risk factor into the index. Moreover, the fuel mix component of Lefevre's index looks at the total supply of a specific fuel as part of the total energy mix, but in the case of natural gas there was some manipulation whether the national market structure is competitive or regulated. 
We opted to build the fuel mix component of the equation by taking the imported share of the specific fuel as part of the fuel mix instead of the total supply for the index.

\section{Population growth}

Population is seen a key determinant of energy consumption. Holdren (1991) found that population growth was responsible for $52 \%$ of the global energy growth since 1850 . Whether there is an association between population growth rates and energy productivity changes is less certain. Metcalf (2008) and Jimenez and Mercado (2014) hypothesize that fast growing populations may add more energy-efficient infrastructure than slower growing areas. However, they also note that if infrastructure development fails to keep pace with population growth, it can lead to greater energy use because of traffic congestion and other infrastructure pressures. Population growth data was retrieved from the World Bank Indicators.

\section{Urbanization}

Empirical research by Jones (1989) found that urbanization alone can be a major factor that drives increases in energy consumption. The relationship between urbanization and energy productivity may be more nuanced. On one hand, moving from rural, agrarian economies to urban and industrialized economies will likely entail more energy intensive activities. Conversely, some urban areas may have energy efficient mass transportation systems that limit congestion, as well as an abundance of energy productive sectors like financial services. The relationship of urbanization and energy productivity is explored using the World Bank's urban population as a percent of total population data.

\section{Income per capita}

Rising income levels may prompt energy productivity responses in several ways. As income per capita rises, energy consumption patterns can increase in a more energy-intensive manner, particularly if the country is industrializing. On the other hand, there may be greater adoption of energy-efficient technology and practices at a certain level of income, along with greater shares of service sector output. We include gross national income (GNI) per capita data from the World Bank to investigate these potential interactions.

\section{Female labor participation rate}

Employment has long been seen as a key determinant of economic growth. Female labor participation rate is used in our analysis to evaluate potential associations between higher labor rates and energy productivity improvements. The female indicator rather than total labor participation rate was selected for several reasons. First, the two are highly correlated and therefore likely to have similar potential explanatory power. Second, female labor participation lags total labor participation and exhibits greater variation across our dataset (Figure 6). More than $44 \%$ of the observations have female labor participation rates below $50 \%$, whereas fewer than $7 \%$ of the total labor participation rate observations fall below that level. Data from the World Bank was used in this analysis. 


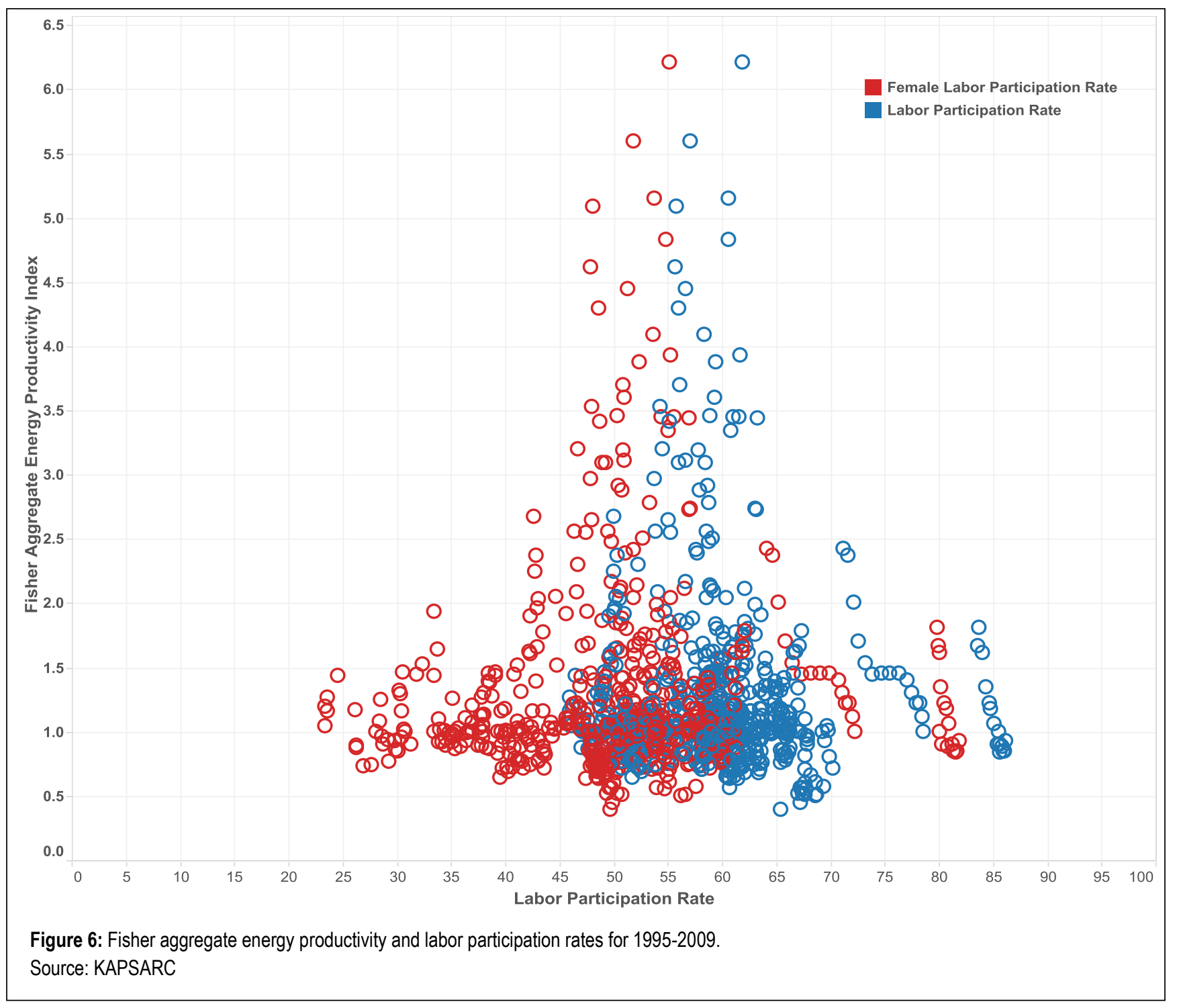

\section{Percent of industrial value added}

The structure of an economy influences aggregate energy productivity. Higher shares of industrial sector economic output are expected to be associated with lower energy productivity compared to service-oriented economies. Whether that aggregate structure influences the relative energy productivity of the sectors, however, is less certain. We include industrial value added as a percent of total value added from the World Bank Indicators to test this relationship.

\section{Investment to capital ratio}

Countries with higher levels of investment are expected to turn over their capital stock faster, which means they may have, on average, more energy-efficient capital than countries with lower investment levels. To assess this potential relationship we include an investment to capital ratio $(\mathrm{I} / \mathrm{K})$ to our analysis. We calculating this using the perpetual inventory method at a $6 \%$ annual discount rate as outlined by Hall and Jones (1999), with gross fixed capital formation and initial physical capital stock data from the World Bank (2011). 


\section{Cluster analysis methodology}

A cluster analysis was used to help identify countries with similar demographic and economic characteristics and to assess whether the country clusters share similar energy productivity trends.

A K-means clustering method was chosen. It included a predetermined random seed using an L2 or Euclidean dissimilarity measure. A panel approach to clustering was used in which all years and countries were included in a single analysis. Variables not in percentages were transformed to their natural logarithms. A Calinski/ Harabasz (1974) criterion was applied to determine the optimal number of clusters from a range of two and eight. The criterion looks at the F-value of a one-way ANOVA with $\mathrm{K}$ representing the number of factor levels, and three clusters is the optimal size for our analysis.

Since we used a panel approach, six countries fell within two clusters over the study period. For example, Estonia's 2008 data point is in Cluster 2 while the remaining years are in Cluster 3. We modified the analysis by limiting countries to a single cluster, determined by the cluster in which it most frequently occurs. This modification affected 21 of the 585 data points.

The Fisher decomposition indices were excluded from the cluster analysis so that an analysis of variance (ANOVA) can test whether the energy productivity indices associated with the countries differ between clusters.

\section{Econometric analysis methodology}

Since the 39 countries in the dataset are quite heterogeneous, a Pedroni (2001) panel co-integration approach with error correction model and period fixed effects was used. The estimation approach assumes that changes in the independent variables-like energy prices-elicit long and short term changes in the dependent variables (in our case, the energy productivity decomposition indexes). Lagged responses and dynamic relationships were tested by adding two period lags to the dependent and independent variables. The lags were limited to two years because of the small number of yearly observations in the dataset.

The number of demographic and economic indicators serving as independent variables was limited to five because, with only 15 years of observations, too many parameters reduces the degrees of freedom and can lead to invalid insights. The independent variables chosen were: weighted average energy prices, GNI per capita, total degree days, investment to capital ratio, and industry's value added as a percent of GDP.

We start by checking the stationarity of the variables by performing unit root tests (URT) using the Augmented Dickey-Fuller Test (Dickey and Fuller, 1981) and Phillips-Perron Test (Phillips and Perron, 1988). The URT results show that the natural logarithmic expressions of EPI, INDUSTRY and GNI_cap are non-stationary at the level but are at the first difference. On the other side, INV_K and TDD are reported as stationary at the level. One reason behind the fact the weather (TDD) seems stationary is that it is analyzed for a short period of time, 15 years, while trends for this variable are usually noticed over of the period of several decades. 
We then run the Pedroni co-integration test (Pedroni, 2001) to check an existence of the long-run relationship among the non-stationary variables. Estimation results are shown in Table 10.

Fully-modified ordinary least squares (FMOLS) and dynamic ordinary least squares (DOLS) estimations were conducted for variables determined to have long-run cointegration relationships (via unit root tests) with the energy productivity indexes. The FMOLS results for long-run relationships are reported in Table 11 as they proved more statistically significant and the responses align with economic theory — such as rising prices leading to great energy productivity.

\begin{tabular}{|c|c|c|c|c|c|c|c|c|c|c|c|c|}
\hline \multicolumn{13}{|c|}{ Alternative hypothesis: common AR coefs. (within-dimension) } \\
\hline & \multicolumn{4}{|c|}{ Fisher Aggregate Energy Productivity } & \multicolumn{4}{|c|}{ Fisher Sectoral Index } & \multicolumn{4}{|c|}{ Fisher Structural Index } \\
\hline & Statistic & Prob. & $\begin{array}{l}\text { Weighted } \\
\text { Statistic }\end{array}$ & Prob. & Statistic & Prob. & $\begin{array}{l}\text { Weighted } \\
\text { Statistic }\end{array}$ & Prob. & Statistic & Prob. & $\begin{array}{l}\text { Weighted } \\
\text { Statistic }\end{array}$ & Prob. \\
\hline Panel v-Statistic & -2.76 & 0.99 & -3.45 & 0.99 & -2.92 & 0.99 & -4.14 & 1.00 & 0.59 & 0.28 & -2.14 & 0.98 \\
\hline Panel rho-Statistic & 5.20 & 1.00 & 5.24 & 1.00 & 4.91 & 1.00 & 5.12 & 1.00 & 4.68 & 1.00 & 4.54 & 1.00 \\
\hline Panel PP-Statistic & -4.23 & 0.00 & -4.62 & 0.00 & -5.26 & 0.00 & -6.06 & 0.00 & -1.67 & 0.05 & -5.01 & 0.00 \\
\hline Panel ADF-Statistic & -8.58 & 0.00 & -10.39 & 0.00 & -8.91 & 0.00 & -10.09 & 0.00 & -5.13 & 0.00 & -6.23 & 0.00 \\
\hline \multicolumn{13}{|c|}{ Alternative hypothesis: individual AR coefs. (between-dimension) } \\
\hline & Statistic & Prob. & & & Statistic & Prob. & & & Statistic & Prob. & & \\
\hline Group rho-Statistic & -2.76 & 0.99 & & & -2.92 & 0.99 & & & 0.59 & 0.28 & & \\
\hline Group PP-Statistic & 5.20 & 1.00 & & & 4.91 & 1.00 & & & 4.68 & 1.00 & & \\
\hline Group ADF-Statistic & -4.23 & 0.00 & & & -5.26 & 0.00 & & & -1.67 & 0.05 & & \\
\hline $\begin{array}{l}\text { Table 10: Results } \\
\text { Source: KAPSAR }\end{array}$ & $\begin{array}{l}\text { S of the } 1 \\
\text { RC }\end{array}$ & ni Cc & ation $t$ & or th & ener & odu & ecomp & OnI & & & & \\
\hline
\end{tabular}

\begin{tabular}{|c|c|c|c|}
\hline Variables & Ln(Fisher_Aggregate_EP) & Ln(Fisher_Sectoral_EP) & Ln(Fisher_Structural) \\
\hline Ln(EPI) & $0.397(0.196)^{* *}$ & $0.56(0.211)^{* * *}$ & $-0.163(0.151)$ \\
\hline Ln(GNI_CAP) & $0.883(0.021)^{* * *}$ & $0.85(0.023)^{* * *}$ & $0.033(0.017)^{* *}$ \\
\hline Ln(Industry) & $-0.319(0.085)^{* * *}$ & $-0.296(0.092)^{* * *}$ & $-0.022(0.066)$ \\
\hline $\begin{array}{l}\text { Table 11: Long-run FMOLS results. Variables in bold represent respective dependent variables. Values in parentheses represent the standard } \\
\text { error and are preceded by the coefficients. }{ }^{* * *},{ }^{* *} \text { and }{ }^{*} \text { indicate significance level at the } 1 \%, 5 \% \text { and } 10 \% \text { respectively. } \\
\text { Source: KAPSARC }\end{array}$ \\
\hline
\end{tabular}


The results show that for all energy productivity indices, two out of four within dimension co-integration tests (ADF and PP tests) suggest a co-integration. This is mirrored by the results of the between dimension tests where the ADF and PP also favor the occurrence of a co-integration.

Building on these results, a long-run relationship between the non-stationary variables is generable in the form of:

$$
\ln \left(y_{t}\right)=\beta_{0}+\beta_{1} \ln \left(G N I_{-} c a p_{t}\right)+\beta_{2} \ln (\text { Industry })+\beta_{3} \ln \left(E P I_{t}\right)+e_{t}
$$

Where $t$ denotes time, et the model's residual, and $\beta$ n the long-run coefficients. A unit root test shows that the coefficients are stationary and that there is a long-run co-integration relationship between the variables. The model was run in both FMOLS and DOLS models, with and without trend.

An error correction model (ECM) was then created to look at the long-run and short-run responses of the five independent variables and the dynamic relationship of the dependent variable. The Engle-Granger approach (Engle and Granger, 1987) was used with the residual et as:

$$
\begin{aligned}
& \Delta \ln (y)=\beta_{0}+\beta_{1} \cdot e_{t-1}+\sum_{i=1}^{2} \beta_{2}^{i} \Delta \ln \left(y_{t-i}\right)+\sum_{i=0}^{2} \beta_{3}^{i} \Delta \ln \left(G N I_{c a p} t-i\right)+ \\
& \sum_{i=0}^{2} \beta_{4}^{i} \Delta \ln \left(\text { Industry } y_{t-i}\right)+\sum_{i=0}^{2} \beta_{5}^{i} \Delta \ln \left(E P I_{t-i}\right)+\sum_{i=0}^{2} \beta_{6}^{i} \Delta \ln (T D D)+ \\
& \sum_{i=0}^{2} \beta_{7}^{i} \Delta \ln \left(i n v_{-} K\right)+\mu_{t}
\end{aligned}
$$

\begin{tabular}{|c|c|c|c|c|c|c|}
\hline \multirow[b]{2}{*}{ Independent Variable } & \multicolumn{2}{|c|}{ DLOG(Fisher_Aggregate_EP) } & \multicolumn{2}{|c|}{ DLOG(Fisher_Sectoral_EP) } & \multicolumn{2}{|c|}{ DLOG(Fisher_Structural) } \\
\hline & Coefficient & std. error & Coefficient & std. error & Coefficient & std. error \\
\hline DLOG(dependent variable, 2 & $-0.174^{* * *}$ & 0.045 & $-0.191^{* * *}$ & 0.045 & 0.067 & 0.050 \\
\hline DLOG(dependent variable, 1 lag) & -0.054 & 0.051 & -0.032 & 0.051 & $0.154^{* * *}$ & 0.049 \\
\hline DLOG(GNI_CAP, 2 lags) & -0.048 & 0.073 & -0.098 & 0.077 & 0.042 & 0.042 \\
\hline DLOG(GNI_CAP, 1 lag) & $-0.301^{* * *}$ & 0.090 & -0.261 *** & 0.094 & -0.052 & 0.049 \\
\hline DLOG(GNI_CAP) & $1.153^{* * *}$ & 0.068 & $1.122^{* * *}$ & 0.073 & 0.026 & 0.041 \\
\hline DLOG(INV_CAP, 2 lags) & $0.113^{* *}$ & 0.048 & 0.069 & 0.051 & 0.021 & 0.029 \\
\hline DLOG(INV_CAP, 1 lag) & 0.049 & 0.049 & 0.033 & 0.052 & -0.015 & 0.030 \\
\hline DLOG(INV_CAP) & 0.002 & 0.046 & -0.118 ** & 0.049 & $0.112^{* * *}$ & 0.028 \\
\hline DLOG(INDUSTRY, 2 lags) & -0.027 & 0.089 & -0.108 & 0.095 & 0.110 ** & 0.054 \\
\hline DLOG(INDUSTRY, 1 lag) & 0.058 & 0.083 & 0.144 & 0.090 & -0.055 & 0.050 \\
\hline DLOG(INDUSTRY) & -0.194 ** & 0.079 & -0.070 & 0.084 & -0.091 * & 0.048 \\
\hline DLOG(EPI, 2 lags) & 0.248 & 0.171 & 0.342 * & 0.183 & -0.084 & 0.104 \\
\hline DLOG(EPI, 1 lag) & -0.064 & 0.180 & 0.019 & 0.193 & -0.045 & 0.108 \\
\hline DLOG(EPI) & $0.687^{* * *}$ & 0.177 & $0.752^{* * *}$ & 0.190 & -0.049 & 0.108 \\
\hline DLOG(TDD, 2 lags) & -0.107 & 0.067 & 0.009 & 0.072 & -0.093 ** & 0.041 \\
\hline DLOG(TDD, 1 lag) & -0.062 & 0.078 & -0.003 & 0.083 & -0.029 & 0.047 \\
\hline DLOG(TDD) & $-0.159 * *$ & 0.072 & -0.059 & 0.076 & -0.081 * & 0.044 \\
\hline$e_{t-1}$ & $-0.328 * * *$ & 0.047 & $-0.347^{* * *}$ & 0.049 & $-0.320 * * *$ & 0.035 \\
\hline Intercept & 0.001 & 0.005 & 0.009 * & 0.005 & -0.004 & 0.003 \\
\hline R-squared & 0.729 & & 0.704 & & 0.311 & \\
\hline Durbin-Watson statistic & 1.882 & & 1.912 & & 1.926 & \\
\hline Akaike info criterion & -2.541 & & -2.400 & & -3.528 & \\
\hline Schwarz criterion & -2.275 & & -2.134 & & -3.262 & \\
\hline
\end{tabular}

Where $i$ is the lag order, et is the error correction term derived from the long-run residuals, $t$ time, $\beta$ the coefficients and $\mu t$ the white noise residuals. Results are presented in Table 12. 


\section{References}

Ang, B. W. (2004) "Decomposition analysis for policymaking in energy:: which is the preferred method?." Energy policy 32.9: 1131-1139.

Ang, B. W., F. L. Liu, and E. P. Chew. (2003) "Perfect decomposition techniques in energy and environmental analysis.” Energy Policy 31.14: 15611566.

Ang, B. W., F. Q. Zhang, and Ki-Hong Choi. (1998) "Factorizing changes in energy and environmental indicators through decomposition." Energy 23.6: 489 -495 .

Ang, B.W., Xu, X.Y. (2013). Tracking industrial energy efficiency trends using index decomposition analysis. Energy Economics 40 1014-1021.

Ang, B.W., and F. L. Liu. (2001) "A new energy decomposition method: perfect in decomposition and consistent in aggregation.” Energy 26.6: 537-548.

Ang, B.W., and F. Q. Zhang. (2000) "A survey of index decomposition analysis in energy and environmental studies.” Energy 25.12: 1149-1176.

Atallah, T.; Gualdi, S.; Lanza, A. (2014). "Enhanced Degree days for 147 countries." KAPSARC Working paper.

Boyd, Gale A., and Joseph M. Roop. (2004) “A note on the Fisher ideal index decomposition for structural change in energy intensity." The Energy Journal: 87-101.

Calinski, T., and J. Harabasz. (1974) "A dendrite method for cluster analysis." Communications in Statistics. Vol. 3, No. 1, pp. 1-27.
Dickey, D. A., \& Fuller, W.A. (1981). Likelihood ratio statistics for autoregressive time series with a unit root. Econometrica: Journal of the Econometric Society (1981): 1057-1072.

DOE. (2014). Energy Department Takes Major Steps to Increase U.S. Energy Productivity and Manufacturing. US Department of Energy press release, September 17, 2014.

Engle, Robert F., and Clive WJ Granger. (1987) Cointegration and error correction: representation, estimation, and testing. Econometrica: journal of the Econometric Society 251-276.

Eurostat. (2014). Heating degree-days by NUTS 2 regions - annual data. Eurostat database available at: http://www.eea.europa.eu/data-and-maps/data/ external/heating-degree-days-annual-data

Federal Ministry of Economic Affairs and Technology. (2006). National Energy Efficiency Action Plan (EEAP) of the Federal Republic of Germany. Submitted in accordance to the EU Directive on "energy end-use efficiency and energy services".

Hall, R.E., Jones, C.I. (1999). Why do some countries produce so much more output per worker than others? Quarterly Journal of Economics 114(1), 83-116.

Holdren, J.P. (1991). Population and the energy problem. Population and Environment. Volume 12, Issue 3, pp 231-255.

IEA. (2007). Energy Security and Climate Policy: Assessing Interactions. International Energy Agency.

IEA. (2014). World Energy Balances. International Energy Agency. 
ILO/IMF/OECD/UNECE/Eurostat/The World Bank "Consumer price index manual: Theory and practice" Geneva, International Labour Office, 2004.

Jimenez, R., Mercado, J. (2014). Energy intensity: A decomposition and counterfactual exercise for Latin American Countries. Energy Economics 42, 161171.

Jones, D.W. (1989). Urbanization and energy use in economic development. The Energy Journal. Vol. 10, No. 4, pp. 29-44.

Lefèvre, Nicolas. (2010) "Measuring the energy security implications of fossil fuel resource concentration" Energy Policy 38.4: 1635-1644

Liddle, Brantley. (2010) "Revisiting world energy intensity convergence for regional differences." Applied Energy 87.10: 3218-3225.

Metcalf, Gilbert E. (2008) "An empirical analysis of energy intensity and its determinants at the state level." The Energy Journal 1-26.

Newell, R.G., Jaffe, A.B., Stavins, R.N. (2006). The effects of economic and policy incentives on carbon mitigation technologies. Energy Economics 28 563578.

Pedroni, P. (2001). Fully modified OLS for heterogeneous cointegrated panels. Advances in Econometrics 15: 93-130.
Phillips, Peter CB, and Perron, P. (1988). Testing for a unit root in time series regression. Biometrika 75.2: 335-346.

Song, Feng, and Xinye Zheng. (2012) "What drives the change in China's energy intensity: Combining decomposition analysis and econometric analysis at the provincial level." Energy Policy 51: 445-453.

Sun, J. W., and B. W. Ang. "Some properties of an exact energy decomposition model." Energy 25.12 (2000): 1177-1188.

Timmer, M.P. (ed). 2012. The World Input-Output Database (WIOD): Contents, Sources and Methods.

Wheeler, D. (2012). Energy + Country Performance Ratings, 2001-2010. Center for Global Development, Working Paper 301.

WIOD Working Paper Number 10, downloadable at http:/www.wiod.org/publications/papers/wiod10.pdf

World Bank. (2011). The Changing Wealth of Nations.

World Bank Database, World Development Indicators, retrieved February 2014. 


\section{About the authors}

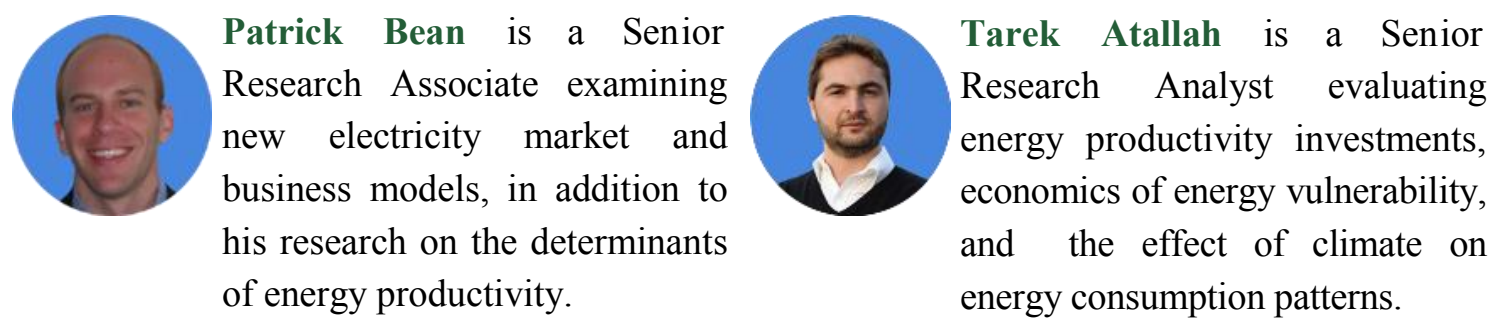

\section{About the project}

Quantifying the determinants of a country's energy productivity trends answers the fundamental question of whether its economy is becoming more energy productive because of technological and efficiency gains, or whether it is due to structural economic shifts. Using three types of analysis, this paper investigates the drivers of energy productivity changes occurring in 39 countries during 1995-2009. The comparison between countries allows for examining whether demographic and economic characteristics contribute to energy productivity performance and the rates of improvement. The findings of the analysis can help inform policy-making efforts focused on improving energy productivity. 